\title{
Introduction to fungal physiology
}

Graeme M. Walker and Nia A. White

This is the accepted manuscript of the book chapter:

Walker, G.M. and White, N.A. 2017. Introduction to fungal

physiology. In: K. Kavangh, ed. Fungi: biology and applications. John Wiley \& Sons.

which has been published in final form at doi:

http://dx.doi.org/10.1002/9781119374312.ch1

This chapter may be used for non-commercial purposes in accordance with the Wiley Terms and Conditions for Self-Archiving 


\title{
CHAPTER 1
}

\section{INTRODUCTION TO FUNGAL PHYSIOLOGY}

\author{
Graeme M. Walker \& Nia A. White
}

\subsection{Introduction}

Fungal physiology refers to the nutrition, metabolism, growth, reproduction and death of fungal cells. It also generally relates to interaction of fungi with their biotic and abiotic surroundings, including cellular responses to environmental stress. The physiology of fungal cells impacts significantly on the environment, industrial processes and human health. In relation to ecological aspects, the biogeochemical cycling of carbon in Nature would not be possible without the participation of fungi acting as primary decomposers of organic material. Furthermore, in agricultural operations fungi play important roles as mutualistic symbionts, pathogens and saprophytes, where they mobilize nutrients and affect the physico-chemical environment, or can be exploited as agents of biocontrol or as bio-fertilizers. Fungal metabolism is also responsible for the detoxification of organic pollutants and for bioremediating heavy metals and other recalcitrant chemicals in the environment (including waste- and ground-waters). The production of many economically important industrial commodities relies on the exploitation of yeast and fungal metabolism and these include such diverse products as whole foods, food additives, fermented beverages, antibiotics, probiotics, pigments, pharmaceuticals, biofuels, enzymes, vitamins, organic and fatty acids and sterols. More negatively, fungi can cause considerable disease, spoilage and decay of important artefacts, commodities and materials, buildings and of course food supplies. In terms of human health, some yeasts and fungi represent major opportunistic life-threatening pathogens, whilst others are life-savers as they provide antimicrobial and chemotherapeutic agents. In 
modern biotechnology, several yeast species are being exploited as hosts for the expression of human therapeutic proteins following recombinant DNA and gene editing technologies (see Chapter 9). Recently, the application of gene editing using CRISPR/Cas is leading to a revolution in fungal genetic engineering (see Chapter 2). Furthermore, an international synthetic biology research consortium, called Sc-2.0, has embarked on the construction of a completely synthetic version of S. cerevisiae. This would represent the world's first fully synthetic eukaryotic genome! In addition to the direct industrial exploitation of yeasts and fungi, it is important to note that these organisms, most notably the yeast Saccharomyces cerevisiae, play increasingly significant roles as model eukaryotic cells in furthering our fundamental knowledge of biological and biomedical science. This is especially the case now that numerous fungal genomes have been completely sequenced and the information gleaned from fungal genomics and proteomics is providing valuable insight into human genetics and heritable disorders. However, knowledge of cell physiology is essential if the functions of many of the currently unknown fungal genes, including "synthetic" ones, are to be fully elucidated.

It is apparent, therefore, that fungi are important organisms for human society, health and well-being and that studies of fungal physiology are very pertinent to our understanding, control and exploitation of this group of microorganisms. This Chapter describes some basic aspects of fungal cell physiology, focusing primarily on nutrition, growth and metabolism in unicellular yeasts and filamentous fungi.

\subsection{Morphology of yeasts and fungi}

There are a diversity of yeast and fungal cellular morphologies. Most higher fungi are filamentous, yeasts grow as unicells, and some primitive fungi such as the 
chytridomycota grow as individual rounded cells or dichotomous branched chains of cells with root like rhizoids for attachment to a nutrient resource. Here we will consider the most common growth forms, the filamentous fungi and unicellular yeasts.

\subsubsection{Filamentous fungi}

The gross morphologies of macrofungi and microfungi are varied and often apparent throughout the environment (see Plate 1.1). For example, we can easily recognise a variety of mushrooms and toadstools, the sexual fruiting bodies of certain macro fungi (the higher fungi Asomycota and Basidiomycota and related forms), during a walk through pasture or woodland. Microfungi (the moulds) are also diverse and are often observed on decaying foods and detritus, whereas many, including the coloured rusts, smuts and mildews, are common plant pathogens. Closer inspection of these visible structures, however, reveals that all are composed of aggregated long, branching threads termed hyphae (singular: hypha), organised to support spores for reproduction and dissemination. The hyphae of these aerial structures extend and branch within the supporting substratum as a network, termed a mycelium, from which the apically growing hyphae seek out, exploit and translocate available nutrients. Apically growing hyphae usually have a relatively constant diameter ranging from $1-30 \mu \mathrm{m}$ or more, depending on fungal species and growth conditions. Filamentous fungi may be cultivated within the laboratory on a variety of different liquid or solid media. On agar, the radially expanding colonial growth form of the fungal mycelium is most evident, extending from an inoculum, on, within and sometimes above the substrate, forming a near spherical 3-dimensional colony. This 
radiating, circular pattern is also visible during the growth of fairy ring fungi in grassland and as ringworm infections of the skin (Plate 1.1).

The hyphae of individual fungi may (theoretically) extend endlessly via apical growth, provided they are supported with appropriate nutrients and other environmental conditions. Eucarpic fungi are therefore spatially and temporally indeterminate organisms, and unlike animal, plant and other microbial individuals, have no predetermined maximum size or age. The mycelium is not, however, simply a homogeneously extending entity, but displays considerable developmental plasticity. Different interconnected regions of the fungal mycelium may grow, branch, anastomose (fuse), age, die, sporulate, and display varying physiological and biochemical activities at different times or even simultaneously, depending on local micro-environmental conditions. Thus, colonies growing on relatively homogeneous media may be pigmented, exhibit different morphological sectors, produce aerial structures, grow as fast-effuse or slow-dense forms, and even exhibit rhythmic growth As well as reproductive structures and substrate mycelium, certain higher fungi, most notably the basidiomycetes, when growing within an environment where nutrients are distributed heterogeneously, can differentiate into long string-like structures called rhizomorphs or cords. These linear organs have evolved to rapidly explore for, connect and translocate water and nutrients between patches of resource (e.g. pieces of fallen timber on the forest floor or from tree root to tree root). Accordingly, many, particularly mature rhizomorphs, contain internal vessel hyphae which possess a wide diameter, forming a channel running along the organ. The peripheral hyphae are often closely packed and melanized for insulation (Plate 1.1) 
Filamentous fungi and yeasts are simply different styles of fungal growth suitable for occupation of different habitats and produced by differing cell growth polarities. Many species termed dimorphic fungi can adopt either the hyphal or unicellular yeast forms according to environmental circumstances. For example, certain important human and animal pathogens exist as yeast forms mobilised in body fluids but are able to form hyphae or pseudohyphae for tissue invasion.

\subsubsection{Yeasts}

Yeasts are unicellular (mostly Ascomycete, Basidiomycete or members of the Deuteromycete group) fungi that divide asexually by budding or fission and whose individual cell size can vary widely from $2-3 \mu \mathrm{m}$ to $20-50 \mu \mathrm{m}$ in length and $1-10 \mu \mathrm{m}$ in width. Saccharomyces cerevisiae, commonly referred to as brewer's or baker's yeast, is generally ellipsoid in shape with a large diameter of $5-10 \mu \mathrm{m}$ and a small diameter of around $5 \mu \mathrm{m}$ (Figure 1.1). There is great diversity in cell shapes and modes of cellular reproduction in the yeasts, as summarised in Tables 1.1.

\section{$<$ FIGURE 1.1 HERE $>$}

The morphology of agar-grown yeasts show great diversity in terms of colour, texture and geometry (peripheries, contours) of giant colonies. Several yeasts are pigmented and the following colours may be visualised in surface-grown colonies: cream (e.g. S. cerevisiae); white (e.g. Geotrichum candidum); black (e.g. Aureobasidium pullulans); pink (e.g. Phaffia rhodozyma); red (e.g. Rhodotorula rubra); orange (e.g. Rhodosporidium spp.) and yellow (e.g. Cryptococcus laurentii). The pigments of some yeasts have biotechnological uses, including astaxanthin from P. rhodozyma in aquacultural feed supplements for farmed salmon (that are unable to synthesise these natural pink compounds). 


\subsection{Ultrastructure and function of fungal cells}

\subsubsection{The fungal cell surface}

The cell envelope in yeasts and fungi is the peripheral structure that encases the cytoplasm and comprises the plasma membrane, the periplasm, the cell wall and additional extracellular structural components (such as fimbriae and capsules). The cell wall represents a dynamically forming exoskeleton that protects the fungal protoplast from the external environment and defines directional growth, cellular strength, shape and interactive properties (Figure 1.2). In filamentous fungi, cell wall formation and organisation is intimately bound to the process of apical growth. Thus, for example in Neurospora crassa, the wall is thin (approx. 50nm) at the apex but becomes thicker (approx. 125nm) at $250 \mu \mathrm{m}$ behind the tip. The plasma membrane component of the fungal cell envelope is a phospholipid bilayer interspersed with globular proteins that dictates entry of nutrients and exit of metabolites and represents a selective barrier for their translocation. Ergosterol is the major sterol found in the membranes of fungi, in contrast to the cholesterol found in the membranes of animals and phytosterols in plants. This distinction is exploited during the use of certain antifungal agents used to treat some fungal infections, and can be used as an assay tool to quantify fungal growth. The periplasm, or periplasmic space, is the region external to the plasma membrane and internal to the cell wall. In yeast cells, it comprises secreted proteins (mannoproteins) and enzymes (such as invertase and acid phosphatase) that are unable to traverse the cell wall. In filamentous fungi, the cell membrane and wall may be intimately bound as hyphae are often resistant to plasmolysis. $<$ INSERT FIGURE 1.2 >

Fungal cell surface topological features can be visualised using scanning electron microscopy (SEM) and nanometre resolution achieved using atomic force microscopy 
(AFM). The latter is beneficial as it can be employed with unfixed, living cells and avoids potentially misleading artefacts that may arise when preparing cells for electron microscopy.

Ultrastructural analysis of fungal cell walls reveals a thick, complex fibrillar network. The cell walls of filamentous fungi are mainly composed of different polysaccharides according to taxonomic group. For example, they may contain either chitin, glucans, mannoproteins, chitosan, polyglucuronic acid or cellulose (absent from true fungi), together with smaller quantities of proteins and glycoproteins (Table 1.2). Generally, the semi-crystalline microfibrillar components are organised in a network mainly in the central cell wall region and are embedded within an amorphous matrix. Bonding occurs between certain components behind the extending hyphal tip, thereby strengthening the entire wall structure. The processes of endocytosis and exocytosis occur around apical and subapical regions and serve to both shape hyphal growth and interactions with the environment (Figure 1.2). There is evidence to suggest that the cell wall is a dynamic structure where considerable quantitative and qualitative differences occur not only between different fungal species, but also between different morphological forms of the same species and even in response to environmental stress. For example, a class of hydrophobic proteins called hydrophobins are localised within the aerial growth or appresoria (terminal swellings involved in infection) of certain fungi, whereas pigmented melanins are often found within some fungal cell walls to insulate against biotic and abiotic stresses.

\section{$<$ INSERT TABLE 1.2 HERE $>$}

The hyphae of higher fungi extend via tip growth followed by cross-wall formation or septation, whereas the lower fungi remain aseptate (except when segregating spores or in damaged colony regions). Septa may offer some structural 
support to hyphae. Significantly, septa serve to compartmentalise hyphae but are typically perforated, thereby permitting passage and communication of cytoplasm or even protoplasm between compartments. However, septal pores can become blocked by Woronin bodies or other materials. This aids morphological and biochemical differentiation and serves to seal-off stressed or damaged hyphae from undamaged colony regions. Again, different pore types are representative of different taxonomic groups and species (Table 1.2).

In yeasts, the cell wall provides stability and protection to the cells and its structure comprises polysaccharides (predominantly $\beta$-glucans for rigidity), proteins (mainly mannoproteins on the outermost layer for determining porosity), together with some lipid, chitin (eg. in bud scar tissue) and inorganic phosphate material. Figure 1.3 shows the composition and structure of the S. cerevisiae cell wall. Hyphal cell walls generally contain fewer mannans than yeast cell forms, and such changes in composition are even observed during the transition from unicellular to mycelial growth of dimorphic fungi.

Chitin is also found in yeast cell walls and is a major constituent of bud scars (Figure 1.1). These are remnants of previous budding events found on the surface of mother cells following birth of daughter cells (buds). The chitin-rich bud scars of yeast cells can be stained with fluorescent dyes (e.g. calcoflour white) and this can provide useful information regarding cellular age, since the number of scars represents the number of completed cell division cycles. Outside the cell wall in fungi, several extramural layers may exist including fimbriae and capsules. Fungal fimbriae are long, protein-containing protrusions appearing from the cell wall of certain basidiomycetous and ascomycetous fungi that are involved in cell-cell conjugation. Capsules are extracellular polysaccharide-containing structures found in 
basidiomycetous fungi that are involved in stress protection. In Cryptococcus neoformans (the pathogenic yeast state of Filobasidiella neoformans) the capsule may determine virulence properties and evasion from macrophages. One extrahyphal substance, the polymer pullulan, is produced commercially from Aureobasidium pullulans, and is used in the production of oral hygiene products $<$ FIGURE 1.3

\section{HERE $>$}

\subsubsection{Subcellular architecture and organelle function}

Transmission electron microscopy of ultrathin sections of fungal cells reveals intracellular fine structure (Figures $1.2 \& 1.4$ ). Sub-cellular compartments (organelles) are bathed in an aqueous cytoplasm containing soluble proteins and other macromolecules together with low-molecular weight metabolites.

However, the hyphae of central (and therefore older) colony regions of filamentous fungi may become devoid of protoplasm and organelles, as protoplasmic components are driven forward or are recycled, to support the growth of actively growing hyphal-tips. Cytoplasmic components additionally comprise microbodies, ribosomes, proteasomes, lipid particles and a cytoskeletal network. The latter confers structural stability to the fungal cytoplasm and consists of microtubules and microfilaments. The following membrane-bound organelles may be found in a typical fungal cell: nucleus, endoplasmic reticulum (ER), mitochondria, Golgi apparatus, secretory vesicles and vacuoles. Several of these organelles form extended membranous systems. For example, the ER is contiguous with the nuclear membrane and secretion of fungal proteins involves inter-membrane trafficking in which the ER, Golgi apparatus, plasma membrane and vesicles all participate. The physiological 
function of the various fungal cell organelles is summarised in Table 1.3. <FIGURE

\subsection{AND TABLE 1.3 HERE>}

The nucleus is the structure that defines the eukaryotic nature of fungal cells. It is bound by a double-membrane and encases the chromosomes in a nucleoplasm. Most yeast and fungi are haploid (singular copies of each chromosome), although some (e.g. S. cerevisiae) may alternate between haploidy and diploidy. Many industrial strains of S. cerevisiae exhibit aneuploidy (odd numbers of chromosomes) or are polyploid (multiple chromosome copies). Chromosomes comprise DNAprotein structures that replicate and segregate to newly-divided cells or hyphal compartments at mitosis. This, of course, ensures that genetic material is passed onto daughter cells or septated compartments at cell division. Yeasts usually contain a single nucleus per cell. However, the hyphal compartments of filamentous fungi may contain one or more nuclei. Monokaryotic basidiomycetes possess one nucleus per compartment whereas dikaryons and heterokaryons possess two or more genetically distinct haploid nuclei. The maintenance of multiple nuclei within individual hyphal compartments allows fungi to take advantage of both haploid and diploid life-styles. This is discussed further in Chapter 2.

In filamentous fungi, a phase-dark near-spherical region, which also stains with iron-haemotoxylin, is evident by light microscopy at the apex during hyphal tip growth. The region is termed the Spitzenkörper, the apical vesicle cluster or centre or apical body, and it consists of masses of small membrane-bound vesicles around a vesicle-free core with emergent microfilaments and microtubules (Figure 1.2). The Spitzenkörper contains differently sized vesicles derived from Golgi bodies, either large vesicles or microvesicles (chitosomes), with varying composition. It orientates to the side as the direction of tip growth changes, and disappears when growth ceases. 
This vesicle supply centre is involved in wall extension and hence tip growth, branching, clamp connection formation (in Basidiomycetes) and germ tube formation.

\subsection{Fungal nutrition and cellular biosyntheses}

\subsubsection{Chemical requirements for growth}

Yeasts and fungi have relatively simple nutritional needs and most species would be able to survive quite well in aerobic conditions if supplied with glucose, ammonium salts, inorganic ions and a few growth factors. Exceptions to this would include for example, obligate symbionts such as the Vesicular-Arbuscular Mycorrhizal fungi (VAM) which require growth of a plant partner for cultivation. Macronutrients, supplied at millimolar concentrations, comprise sources of carbon, nitrogen, oxygen, sulphur, phosphorus, potassium and magnesium; and micronutrients, supplied at micromolar concentrations, comprise trace elements like calcium, copper, iron, manganese and zinc would be required for fungal cell growth (Table 1.4). Some fungi are oligotrophic, apparently growing with very limited nutrient supply, surviving by scavenging minute quantities of volatile organic compounds from the atmosphere. $<$ INSERT TABLE 1.4 HERE $>$

Being chemoorganotrophs, fungi need fixed forms of organic compounds for their carbon and energy supply. Sugars are widely utilised for fungal growth, and can range from simple hexoses like glucose to polysaccharides like starch and cellulose. Some fungi can occasionally utilise aromatic hydrocarbons (e.g. lignin by the whiterot fungi). Table 1.5 outlines the variety of carbon sources which can be utilised by yeasts and filamentous fungi for growth. $<$ INSERT TABLE 1.5 HERE $>$

Fungi are non-diazotrophic (cannot fix nitrogen) and need to be supplied with nitrogenous compounds, either in inorganic form such as ammonium salts, or in organic form such as amino acids. Ammonium sulphate is a commonly used nitrogen 
source in fungal growth media since it also provides a source of utilisable sulphur. Many fungi (but not the yeast S. cerevisiae) can also grow on nitrate, and if able to do so, may also utilize nitrite. Nitrate reductase, followed by nitrite reductase, are the enzymes responsible for converting nitrate to ammonia. Most fungi can assimilate amino acids, amines and amides as nitrogen sources. Most fungi (but not many yeasts) are also proteolytic and can hydrolyse proteins (via extracellularly secreted proteases) to liberate utlisable amino acids for growth. Urea utilisation is common in fungi and some basidiomycotenous yeasts are classed as urease-positive (able to utilise urea) whilst several ascomycotenous yeasts are urease-negative.

In terms of oxygen requirements, most fungi are aerobes and are often described as being microaerophilic (preferring an oxygen tension below that of normal atmospheric). Although yeasts like $S$. cerevisiae are sometimes referred to as facultative anaerobes, they cannot actually grow in strictly anaerobic conditions unless supplied with certain fatty acids and sterols (which they cannot synthesise without molecular oxygen). In fact, there are thought to be very few yeast species that are obligately anaerobic. Unsaturated fatty acids (e.g. oleic acid) and sterols (e.g. ergosterol) are important constituents of the yeast cell membrane, and oxygen is required for their synthesis and to maintain membrane functional integrity and stress resistance. For aerobically respiring yeasts and fungi, oxygen is required as the terminal electron acceptor where it is finally reduced to water in the electron transport chain. Different fungal species respond to oxygen availability in diverse ways and Table 1.6. categorises fungi into different groups on this basis. <TABLE 1.6 HERE> Sulphur sources for fungal growth include sulphate, sulphite, thiosulphate, methionine and glutathione with inorganic sulphate and the sulphur amino acid 
methionine being effectively utilised. Virtually all yeasts can synthesize sulphur amino acids from sulphate, the most oxidized form of inorganic sulphur.

Phosphorus is essential for biosynthesis of fungal nucleic acids, phospholipids, ATP, glycophosphates and polyphosphates. Hence, the phosphate content of fungi is considerable (e.g. in yeast cells, this accounts for around 3-5\% of dry weight; the major part of this is in the form of orthophosphate $\left(\mathrm{H}_{2} \mathrm{PO}_{4}^{-}\right)$which acts as a substrate and enzyme effector). The fungal vacuole can serve as a storage site for phosphate in the form of complexed inorganic polyphosphates (also referred to as volutin granules). Both nitrogen and phosphorus availability may be growth limiting in Nature. Filamentous fungi have evolved a number of biochemical and morphological strategies allowing capture of often poorly available phosphorus within the natural environment. Plants exploit such efficiency during symbioses between their roots and certain mycorrhizal fungi. The major storage form of phosphorus in plants is phytic acid (myo-inositol hexa-dihydrogenphosphate) that is poorly utilised by monogastrics (e.g. humans, pigs, poultry) and fungal (and yeast) phytases have applications in reducing phytate content of foods and feeds (see Chapter 8).

Concerning requirements for minerals, potassium, magnesium and several trace elements are necessary for fungal growth. $\mathrm{K}$ and $\mathrm{Mg}$ are macroelements required in millimolar concentrations primarily as enzyme cofactors, whereas other microelements (trace elements) are generally required in the micromolar range. These include: $\mathrm{Mn}, \mathrm{Ca} \mathrm{Fe}, \mathrm{Zn}, \mathrm{Cu}, \mathrm{Ni}, \mathrm{Co}$, Mo. Table 1.7 summarises the main metals required for fungal growth. Toxic minerals (eg $\mathrm{Ag}, \mathrm{As}, \mathrm{Ba}, \mathrm{Cs}, \mathrm{Cd}, \mathrm{Hg}, \mathrm{Li}, \mathrm{Pb}$ ) adversely affect fungal growth generally at concentrations greater than $100 \mu \mathrm{M}$.

\section{<TABLE 1.7 HERE $>$}


Fungal growth factors are organic compounds occasionally needed in very low concentrations for specific enzymatic or structural roles, but not as energy sources. These include vitamins (e.g. thiamine, biotin), purines, pyrimidines, nucleosides, nucleotides, amino acids, fatty acids and sterols. For fungi to have a growth factor requirement, this indicates that cells cannot synthesise the particular factor resulting in the curtailment of growth without its provision in culture media. Some fungi (e.g. Aspergillus niger, Penicillium chrysogenum) have very simple nutritional needs and are able to synthesise their own growth factors from glucose.

\subsubsection{Fungal cultivation media}

Fungal nutritional requirements are important not only for successful cultivation in the laboratory but also for the optimisation of industrial fermentation processes. In the laboratory, it is relatively easy to grow yeasts and fungi on complex culture media such as malt extract or potato-dextrose agar or broth, which are both carbon rich and in the acidic $\mathrm{pH}$ range. Mushrooms are cultivated on various solidsubstrates depending on provincial availability. Therefore, Agaricus bisporus (common button mushroom) is grown in the UK, US and France on wheat-straw; the padi-straw mushroom (Volvariella volvacea) is grown in South-east Asia on damp rice-straw and in Hong-Kong on cotton waste; and in Japan, the shiitake mushroom (Lentinus edodes) is cultivated on fresh oak logs (see Chapter 6). In industry, media for fungal fermentation purposes needs to be optimised with regard to the specific application and production process. For some industrial processes, growth media may already be relatively complete in a nutritional sense, such as malt wort or molasses for brewing or baker's yeast production, respectively (Table 1.8). However, for other processes, supplementation of agriculturally-derived substrates like corn steep liquor, molasses or malt broth with additional nutrients and growth factors may be necessary. 
For example, for penicillin production by Penicillium spp. the following may constitute a suitable fermentation medium: sucrose ( $3 \mathrm{~g} / \mathrm{L})$, corn steep liquor (100 $\mathrm{g} / \mathrm{L}), \mathrm{KH}_{2} \mathrm{PO}_{4}(1 \mathrm{~g} / \mathrm{L}),\left(\mathrm{NH}_{4}\right)_{2} \mathrm{SO}_{4}(12 \mathrm{~g} / \mathrm{L}), \mathrm{CaCl}_{2} .2 \mathrm{H}_{2} \mathrm{O}(0.06 \mathrm{~g} / \mathrm{L})$, phenoxyacetic acid $(5.7 \mathrm{~g} / \mathrm{L}) \quad$ Whereas, other industrial processes such as the growth of Fusarium graminarium for the production of Quorn ${ }^{\mathrm{TM}}$ mycoprotein, requires culture on a completely defined medium. <TABLE 1.8 HERE>

\subsubsection{Nutrient uptake and assimilation}

Fungal cells utilise a diverse range of nutrients and employ equally diverse nutrient acquisition strategies. Fungi are non-motile, saprophytic (and sometimes parasitic), chemo-organotrophic organisms. They exhibit dynamic interactions with their nutritional environment that may be exemplified by certain morphological changes depending on nutrient availability. For example, the filamentous mode of growth observed at the periphery of certain yeast colonies growing in agar is akin to a foraging for nutrients as observed in certain eucarpic fungi. Metabolic dynamism is also evident in yeasts which, although not avid secretors of hydrolytic enzymes like higher fungi, are nevertheless able to secrete some enzymes to degrade polymers such as starch (as in amylolytic yeasts like Schwanniomyces spp.).

Several cellular envelope barriers to nutrient uptake by fungal cells exist, namely: the capsule, the cell wall, the periplasm and the cell membrane. Although not considered as freely porous structures, fungal cell walls are relatively porous to molecules up to an average molecular mass of around 300Da, and will generally retain molecules greater than around 700Da. Typically, fungi absorb only small soluble nutrients such as monosaccharides and amino acids.

The plasma membrane is the major selectively permeable barrier which dictates nutrient entry and metabolite exit from the fungal cell. Membrane transport 
mechanisms are important in fungal physiology since they govern the rates at which cells metabolise, grow and divide. Fungi possess different modes of passive and active uptake at the plasma membrane: free diffusion, facilitated diffusion, diffusion channels and active transport (Table 1.9). Active transport of nutrients such as sugars, amino acids, nitrate, ammonium, sulphate and phosphate in filamentous fungi involves spatial separation of the ion pumps mostly behind the apex, whereas the symport proteins are active close to the tip. Thus, nutrient uptake occurs at the hyphal tip as it continuously drives into fresh resource, and the mitochondria localised behind the apex supply ATP to support the ion pump and generate proton motive force. <TABLE 1.9 HERE $>$

\subsubsection{Overview of fungal biosynthetic pathways}

Anabolic pathways are energy-consuming, reductive processes which lead to the biosynthesis of new cellular material and are mediated by dehydrogenase enzymes which predominantly use reduced $\mathrm{NADP}^{+}$as the redox cofactor. NADPH is generated by the hexose monophosphate pathway (or Warburg-Dickens pathway) which accompanies glycolysis (see section 1.5a). In S. cerevisiae, up to $20 \%$ of total glucose may be degraded via the hexose monphosphate pathway. This pathway generates cytosolic NADPH (following the dehydrogenation of glucose 6-phosphate using glucose 6-phosphate dehydrogenase and $\mathrm{NADP}^{+}$as hydrogen acceptor) for biosynthetic reactions leading to the production of fatty acids, amino acids, sugar alcohols, structural and storage polysaccharides and secondary metabolites. Besides generating NADPH, the hexose monophosphate pathway also produces ribose sugars for the synthesis of nucleic acids, RNA and DNA and for nucleotide coenzymes, NAD, NADP, FAD and FMN. This is summarised as follows: 
Glucose 6-phosphate $+2 \mathrm{NADP}^{+}{ }_{--}>$Ribulose 5-phosphate $+\mathrm{CO}_{2}+\mathrm{NADPH}+2 \mathrm{H}^{+}$

and complete oxidation of glucose 6-phosphate would result in:

Glucose 6-phosphate $+12 \mathrm{NADP}^{+}->6 \mathrm{CO}_{2}+12 \mathrm{NADPH}+12 \mathrm{H}^{+}+\mathrm{Pi}$

Fungal growth on non-carbohydrate substrates as sole carbon sources (e.g. ethanol, glycerol, succinate and acetate) may lead to gluconeogenesis (conversion of pyruvate to glucose) and polysaccharide biosynthesis. Gluconeogenesis may be regarded as a reversal of glycolysis and requires ATP as energy and NADH as reducing power.

Concerning fungal amino acid biosynthesis, simple nitrogenous compounds such as ammonium may be assimilated into amino acid families, the carbon skeletons of which originate from common precursors of intermediary carbon metabolism.

The two main fungal storage carbohydrates are glycogen and trehalose. Glycogen is similar to starch with $\alpha(1->4)$ glucan linear components and $\alpha(1->6)$ branches. Trehalose (also known as mycose) is a disaccharide of glucose comprising an $\alpha, \alpha(1->1)$ glucoside bond between two $\alpha$-glucose units. Both trehalose and glycogen are synthesised following the formation of UDP-glucose, catalysed by UDPglucose pyrophosphorylase:

UTP + Glucose 1-phosphate -> UDP-glucose + Pyrophosphate

Glycogen is synthesised by glycogen synthase. Glycogen may be metabolised by glycogen phosphorylase when nutrients become limited under starvation conditions and this contributes to the maintenance metabolism of cells by furnishing energy in the form of ATP. In yeast cells, glycogen breakdown is accompanied by membrane sterol biosynthesis (in the presence of some oxygen) and this is important for brewing yeast vitality and successful beer fermentations. The other major storage carbohydrate, trehalose, is synthesized from glucose 6-phosphate and UDP-glucose by trehalose 6-phosphate synthase and converted to trehalose by a phosphatase. In 
addition to a storage role, trehalose is an important translocation material in filamentous forms and is also involved in stress protection in yeasts and fungi, accumulating when cells are subject to environmental insults such as heat shock or osmotic stress, or during plant host-fungal parasite interactions. Trehalose acts by protecting cell membranes against desiccation or thermal damage. Polyols, such as mannitol derived from fructose phosphate and glycerol from the glycolytic intermediate dihydroxyacetone phosphate, are also translocated by fungi. In particular, glycerol is produced as a "compatible solute" in response to osmotic stress to counteract the loss of intracellular water (see section 1.6.1). Glycerol is also a yeast fermentation by-product and contributes to the viscosity or mouthfeel of alcoholic beverages such as beer and wine.

\subsubsection{Fungal cell wall growth}

The structural polysaccharides in fungal cell walls include mannans, glucans and chitin and are synthesised from sugar nucleotides substrates formed by pyrophosphorylase enzymes. For example:

$$
\begin{aligned}
& \text { Glucose 1-phosphate + UTP ->UDP-glucose + PPi } \\
& \text { Mannose 1-phosphate + GTP -> GDP-mannose + PPi }
\end{aligned}
$$

Glucan synthesis involves plasma membrane-associated glucan synthetases for assembly of $\beta-1,3$ linkages and $\beta-1,6$ branches of cell wall glucan. Chitin (a polymer of $\mathrm{N}$-acetylglucosamine) is an important fungal cell wall structural component and is involved in the yeast budding process and in dimorphic transitions from yeast to filamentous forms. Chitin synthetases catalyze the transfer of $\mathrm{N}$-acetylglucosamine from UDP-N-acetylglucosamine to a growing chitin polymer within the fungal cell wall. The mannoproteins predominantly of unicellular forms are pre-assembled within the Golgi and are delivered to the cell wall via vesicles from the vesicle supply centre. Various vesicles containing cell wall-synthetic enzymes, wall-lytic enzymes, enzyme 
activators and certain pre-formed wall components, are transported to the tip where they fuse with the plasma membrane and release their contents, which together with substrates delivered from the cytosol, facilitate synthesis of the growing cell wall.

\subsection{Fungal metabolism}

\subsubsection{Carbon catabolism}

Being chemoorganotrophs, fungi derive their energy from the breakdown of organic compounds. Generally speaking, fungi, but few yeast species, extracellularly breakdown polymeric compounds by secreted enzymes prior to utilization of monomers as carbon and energy sources. Due to their relatively large size (20-60 $\mathrm{KDa}$ ), enzymes assembled by the Golgi are transported in vesicles to be secreted from sites of cell growth, essentially from extending hyphal tips. Enzymes may either become linked to the cell wall as wall bound enzymes or may diffuse externally to decay substrates within the local environment.

Some examples follow of hydrolytic, oxidative, peroxidative and free radical generating enzyme systems produced by fungi for the degradation of polymeric compounds:

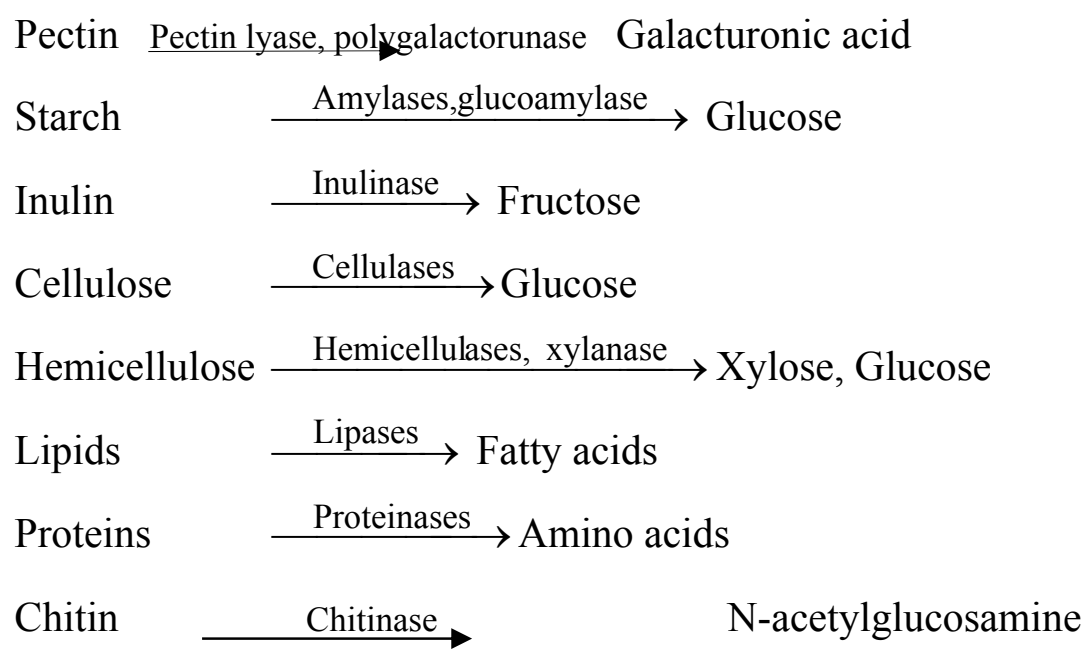

Lignin Ligninase; manganese peroxidase; laccase; glucose oxidase

Variety of

largely phenolic products 
Several lipolytic yeasts are known (eg Candida rugosa, Yarrowia lipolytica) which secrete lipases to degrade triacylgycerol substrates to fatty acids and glycerol. In wood, the cellulose and hemicellulose components are embedded within a heteropolymeric 3-D lignin matrix, thus forming a complex lignocellulose material. Only certain filamentous basidiomycete or ascomycete fungi are able to degrade the recalcitrant lignin component making available the cellulose or hemicellulose components. These are known as white-rot fungi due to resultant colouration of the delignified wood. Such fungi employ a cocktail of oxidative (including laccases) and peroxidative enzymes, together with hydrogen peroxide generating enzyme systems, to attack at least 15 different inter-unit bond types extant within the lignin polymer. The manganese and lignin peroxidase enzyme systems operate by releasing highly reactive but transient oxygen free radicals, which bombard and react with parts of the lignin molecule, generating a chain of chemical oxidations and producing a range of mainly phenolic end products. White-rot fungi have applications in, for example, upgrading lignocellulose waste for animal feed, paper production and bleaching, the bioremediation of contaminated land and water and (potentially) for biofuel production (e.g. pre-treatment of lignocellulosic biomass for second-generation bioethanol). Brown-rot and soft-rot (in wet wood) fungi are only able to degrade the cellulose and hemicellulose components of wood. Cellulose decomposition involves the synergistic activity of endoglucanases (that hydrolyse the internal bonds of cellulose), exoglucanases (that cleave cellobiose units from the end of the cellulose chain) and glucosidases (that hydrolyse cellobiose to glucose). Initial attack of cellulose microfibrills within the cell wall may involve the generation of hydrogen peroxide. Commercially available cellulolytic enzymes are produced from filamentous fungal cultures, notably Trichoderma reesei. 
Catabolic pathways are oxidative processes which remove electrons from intermediate carbon compounds and use these to generate energy in the form of ATP. The catabolic sequence of enzyme-catalyzed reactions that convert glucose to pyruvic acid is known as glycolysis, and this pathway provides fungal cells with energy, together with precursor molecules and reducing power (in the form of NADH) for biosynthetic pathways. Therefore, in serving both catabolic and anabolic functions, glycolysis is sometimes referred to as an amphibolic pathway. Glycolysis may be summarised as follows:

$$
\text { Glucose }+2 \mathrm{ADP}+2 \mathrm{Pi}+2 \mathrm{NAD}^{+} \rightarrow 2 \text { Pyruvate }+2 \mathrm{ATP}+2 \mathrm{NADH}^{+}+2 \mathrm{H}^{+}
$$

During glycolysis, glucose is phosphorylated using ATP to produce fructose 1,6-biphosphate which is then split by aldolase to form two triose phosphate compounds. Further phosphorylation occurs forming two triose diphosphates from which four $\mathrm{H}$ atoms are accepted by two molecules of $\mathrm{NAD}^{+}$. In the latter stages of glycolysis, four molecules of ATP are formed (by transfer of phosphate from the triose diphosphates to ADP) and this results in the formation of two molecules of pyruvic acid. ATP production (2 molecules net) during glycolysis is referred to as substrate-level phosphorylation.

In yeast cells undergoing alcoholic fermentation of sugars under anaerobic conditions, $\mathrm{NAD}^{+}$is regenerated in terminal step reactions from pyruvate. In the first of these, pyruvate is decarboxylated (by pyruvate decarboxylase) before a final reduction, catalyzed by alcohol dehydrogenase $(\mathrm{ADH})$ to ethanol. Such regeneration of $\mathrm{NAD}^{+}$prevents glycolysis from stalling and maintains the cell's oxidationreduction balance and ATP production. Additional minor fermentation metabolites are produced by fermenting yeast cells, including glycerol, fusel alcohols (e.g. isoamyl alcohol), esters, (e.g. ethyl acetate) organic acids (e.g. citrate, succinate, acetate) and 
aldehydes (e.g. acetaldehyde). Such compounds are important in flavour development in alcoholic beverages such as beer, wine and whisky.

Aerobic dissimilation of glucose by fungi leads to respiration which is the major energy-yielding metabolic route and involves glycolysis, the citric acid cycle, the electron transport chain and oxidative phosphorylation. Yeasts, in particular $S$. cerevisiae, are unique microorganisms in that they can switch from respiration to fermentation, and vice versa, depending on the prevailing growth conditions. In addition to glucose, many carbon substrates can be respired by fungi including: pentose sugars (e.g. xylose), sugar alcohols (e.g. glycerol), organic acids (e.g. acetic acid), aliphatic alcohols (eg methanol, ethanol), hydrocarbons (e.g. n-alkanes) and aromatic compounds (e.g. phenol). Fatty acids are made available for fungal catabolism following extracellular lipolysis of fats and are metabolised by $\beta$-oxidation in mitochondria.

During glucose respiration under aerobic conditions, pyruvate enters the mitochondria where it is oxidatively decarboxylated to acetyl CoA by pyruvate dehydrogenase which acts as the link between glycolysis and the cyclic series of enzyme catalyzed reactions known as the citric acid cycle (or Krebs cycle). This cycle represents the common pathway for the oxidation of sugars and other carbon sources in yeasts and filamentous fungi and results in the complete oxidation of one pyruvate molecule to: $2 \mathrm{CO}_{2}, 3 \mathrm{NADH}, 1 \mathrm{FADH}_{2}, 4 \mathrm{H}^{+}$and $1 \mathrm{GTP}$. Like glycolysis, the citric acid cycle is amphibolic since it performs both catabolic and anabolic functions, the latter providing intermediate precursors (e.g. oxaloacetate and $\alpha$-ketoglutarate) for the biosynthesis of amino acids and nucleotides. The removal of intermediates necessitates their replenishment to ensure continued operation of the citric acid cycle. 
The glyoxylate cycle is an example of such an anaplerotic reaction and involves the actions of the enzymes pyruvate carboxylase:

Pyruvate $+\mathrm{CO}_{2}+\mathrm{ATP}+\mathrm{H}_{2} \mathrm{O}->$ Oxaloacetate + ADP $+\mathrm{Pi}$

and phosophoenolpyruvate carboxykinase:

Phosphoenolpyruvate $+\mathrm{CO}_{2}+\mathrm{H}_{2} \mathrm{O}->$ Oxaloacetate $+\mathrm{H}_{3} \mathrm{PO}_{4}$

During the citric acid cycle, dehydrogenase enzymes transfer hydrogen atoms to the redox carriers $\mathrm{NAD}^{+}$and $\mathrm{FAD}$, which become reduced. On the inner membrane of mitochondria, these reduced coenzymes are then re-oxidized and oxygen is reduced to water via the electron transport chain. Energy released by electron transfer is used to synthesize ATP by a process called oxidative phosphorylation. The chemiosmotic theory describes proton pumping across the inner mitochondrial membrane to create a transmembrane proton gradient $(\Delta \mathrm{pH})$ and a membrane potential difference. Together, these comprise the proton motive force that is the driving force for ATP synthesis. Each pair of electrons in NADH yields about 2.5 ATP while residual energy is largely dissipated as metabolic heat. Since mitochondria are impermeable to NADH, this reduced coenzyme generated in the cytoplasm during glycolysis is "shuttled" across the mitochondrial membrane using either the glycerophosphate shuttle (that uses NADH to reduce dihydroxyacetone phosphate to glycerol 3-phosphate) or the malate shuttle (that uses NADH to reduce oxaloacetate to malate). These processes enable molecules to be oxidized within mitochondria to yield reduced cofactors which in turn are oxidized by the electron transport chain.

Fungi use molecular oxygen as a terminal electron acceptor in aerobic respiration in different ways (Table 1.10). Some yeasts, including S. cerevisiae, exhibit alternative respiration characterised by insensitivity to cyanide but sensitivity to azide. <TABLE 1.10 HERE $>$

\subsubsection{Nitrogen metabolism}


Fungi assimilate simple nitrogenous sources for the biosynthesis of amino acids and proteins. For example, ammonium ions are readily utilised and can be directly assimilated into the amino acids glutamate and glutamine that serve as precursors for the biosynthesis of other amino acids. Proteins can also be utilised following release of extracellular protease enzymes. Glutamate is a key compound in both nitrogen and carbon metabolism and glutamine synthetase is important as it catalyzes the first step in pathways leading to the synthesis of many important cellular macromolecules. Other important enzymes of fungal nitrogen metabolism include glutamate dehydrogenase and glutamate synthase (glutamine amide: 2-oxoglutarateaminotransferase, or GOGAT), the latter requiring ATP. When glutamine synthetase is coupled with glutamate synthase this represents a highly efficient "nitrogenscavenging" process for fungi to assimilate ammonia into amino acids and citric acid cycle intermediates. The particular route(s) of ammonium assimilation adopted by fungi depend on the concentration of available ammonium ions and the intracellular amino acid pools.

Some yeasts (but not $S$. cerevisiae) and fungi can use nitrate as a sole source of nitrogen through the activities of nitrate reductase:<smiles>[CH]C[Sn](=O)[O-]</smiles>

and nitrite reductase:<smiles></smiles>

The resulting ammonium ions can then be assimilated into glutamate and glutamine that represent end products of nitrate assimilation by yeasts.

Urea can also be utilised following its conversion to ammonium by urea aminohydrolase (urea carboxylase plus allophanate hydrolase): 


$$
\mathrm{NH}_{2} \mathrm{CONH}_{2}+\mathrm{ATP}+\mathrm{HCO}_{3}^{-}->\mathrm{NH}_{2} \mathrm{CONHCOO}^{-} \rightarrow 2 \mathrm{NH}_{4}^{+}+2 \mathrm{HCO}_{3}^{-}
$$

Amino acids can either be assimilated into proteins or dissimilated by decarboxylation, deamination, transamination and fermentation. Amino acid degradation by yeasts and fungi yields both ammonium and glutamate. During fermentation, yeasts may produce higher alcohols or fusel oils such as isobutanol and isopentanol following amino acid deamination and decarboxylation. These represent important yeast-derived flavour constituents in fermented beverages.

\subsection{Fungal growth and reproduction}

\subsubsection{Physical requirements for growth}

Most yeast and fungal species thrive in warm, sugary, acidic and aerobic conditions. The temperature range for fungal growth is quite wide, but generally speaking most species grow very well around $25^{\circ} \mathrm{C}$. Low-temperature psychrophilic fungi and high-temperature thermophilic fungi do, however, exist in nature. Fungal growth at various temperatures depends not only on the genetic background of the species but also on other prevailing physical growth parameters and nutrient availability. With regard to high temperature stress (or heat shock) on fungal cells, thermal damage can disrupt hydrogen bonding and hydrophobic interactions leading to general denaturation of proteins and nucleic acids. Fungi, of course, have no means of regulating their internal temperature and the higher the temperature, the greater the cellular damage with cell viability declining when temperatures increases beyond growth optimal levels. Temperature optima vary greatly in fungi with those termed "thermotolerant" growing well above $40^{\circ} \mathrm{C}$. Thermotolerance relates to the transient 
ability of cells subjected to high temperatures to survive subsequent lethal exposures to elevated temperatures, such that intrinsic thermotolerance is observed following a sudden heat shock (e.g. to $50^{\circ} \mathrm{C}$ ), whereas induced thermotolerance occurs when cells are pre-conditioned by exposure to a mild heat shock (e.g. 30 minutes at $37^{\circ} \mathrm{C}$ ) prior to a more severe heat shock. Heat-shock responses in fungi occur when cells are rapidly shifted to elevated temperatures and if this is sub-lethal, induced synthesis of a specific set of proteins, the highly conserved "heat-shock proteins" (Hsps) occurs. Hsps play numerous physiological roles, including thermo-protection.

High water activity, $a_{w}$, is required for growth of most fungi with a minimum $\mathrm{a}_{\mathrm{w}}$ of around 0.65. Water is absolutely essential for fungal metabolism, and any external conditions which result in reduced water availability to cells (i.e. "osmostress") will adversely affect cell physiology. The term water potential refers to the potential energy of water and closely relates to the osmotic pressure of fungal growth media. Certain fungal species, for example, the yeast Zygosaccharomyces rouxii, and some Aspergillus species are able to grow in low water potential conditions (i.e. high sugar or salt concentrations) and are referred to as osmotolerant or zerotolerant. By comparison, S. cerevisiae is generally regarded as a nonosmotolerant yeast. Mild water stress, or hyper-osmotic shock, occurs in fungi when cells are placed in a medium with low water potential brought about by increasing the solute (e.g. salt, sugar) concentration. Conversely, cells experience a hypo-osmotic shock when introduced to a medium of higher osmotic potential (due to reducing the solute concentration). Fungi are generally able to survive such short-term shocks by altering their internal osmotic potential (e.g. by reducing intracellular levels of $\mathrm{K}^{+}$or glycerol). Glycerol is an example of a compatible solute that is synthesised in order to maintain low cytosolic water activity when the external solute concentration is high. 
Glycerol can effectively replace cellular water, restore cell volume and enable fungal metabolism to continue. Trehalose, arabitol and mannitol can similarly protect against osmotic stress. Evidence suggests that the accumulation of compatible solutes is attributed not only to their synthesis but also to control of membrane fluidity thus preventing their leakage to the external environment.

As for $\mathrm{pH}$, most fungi are acidiophilic and grow well between $\mathrm{pH}$ 4-6 but many species are able to grow, albeit to a lesser extent, in more acidic or alkaline conditions (around $\mathrm{pH} 3$ or $\mathrm{pH} \mathrm{8,} \mathrm{respectively).} \mathrm{Fungal} \mathrm{cultivation} \mathrm{media} \mathrm{acidified}$ with organic acids (e.g. acetic, lactic acids) are more inhibitory to growth compared with those acidified with mineral acids (e.g. hydrochloric, phosphoric acids) because organic acids can lower intracellular $\mathrm{pH}$ (following their translocation across fungal plasma membranes). Exposure to organic acids leads to cells exhausting their energy (ATP) when endeavouring to maintain $\mathrm{pH}$ homeostasis through the activities of proton-pumping ATPase in the plasma membrane. This forms the basis of action of weak acid preservatives in inhibiting the growth of food spoilage fungi. Many filamentous fungi can alter their local external $\mathrm{pH}$ by selective uptake and exchange of ions $\left(\mathrm{NO}_{3}{ }^{-}\right.$or $\left.\mathrm{NH}_{4}^{+} / \mathrm{H}^{+}\right)$, or by excretion of organic acids such as oxalic acid.

Other physical parameters influencing fungal physiology include radiation (light or UV may elicit mycelial differentiation and sporulation in some fungi that produce airborne spores), aeration, pressure, centrifugal force and mechanical shear stress.

\subsubsection{Cellular reproduction}

Fungal growth involves transport and assimilation of nutrients followed by their integration into cellular components followed by biomass increase and eventual cell division (as in yeasts) or septation (as in higher fungi). The physiology of 
vegetative reproduction and its control in fungi has been most widely studied in two model eukaryotes, the budding yeast, Saccharomyces cerevisiae, and the fission yeast, Schizosaccharomyces pombe.

Budding is the most common mode of vegetative reproduction in yeasts and multilateral budding is typical in ascomycetous yeasts (Table 1.11). In S. cerevisiae, buds are initiated when mother cells attain a critical cell size and this coincides with the onset of DNA synthesis. The budding processes results from localized weakening of the cell wall and this, together with tension exerted by turgor pressure, allows extrusion of cytoplasm in an area bounded by a new cell wall. Cell wall polysaccharides are mainly synthesized by glucan and chitin synthetases. Chitin is a polymer of $\mathrm{N}$-acetylglucosamine and this material forms a ring between the mother cell and the bud that will eventually form the characteristic bud scar after cell division. Under optimised growth conditions, budding yeasts, typified by $S$. cerevisiae, can complete their budding cell division cycle in around 2 hours.

\section{<TABLE 1.11 HERE>}

Fission yeasts, typified by Schizosaccharomyces spp, divide exclusively by forming a cell septum, which constricts the cell into two equal-sized daughters. In Schiz. pombe, newly divided daughter cells grow in length until mitosis is initiated when cells reach a constant cell length (about $14 \mu \mathrm{m}$ ). The cell septum in Schiz. pombe forms by lateral growth of the inner cell wall (the primary septum) and proceeds inwardly followed by deposition of secondary septa. Cellular fission, or transverse cleavage, is completed in a manner resembling the closure of an iris diaphragm.

In certain yeast species, the presence or absence of pseudohyphae and true hyphae can be used as taxonomic criteria (e.g. the ultrastructure of hyphal septa may discriminate between certain ascomycetous yeasts). Some yeasts grow with true hyphae initiated from germ tubes (eg Candida albicans), but others (including $S$. 
cerevisiae) may grow in a pseudohyphal fashion when starved of nutrients or when subjected to environmental stress. Filamentous growth of yeasts by hyphal or pseudohyphal extension represents a different developmental pathway that is generally reversible. In other words, cells can revert to yeast unicellular growth in more conducive growth conditions indicating that a filamentous mode of growth represents an adaptation by yeast to foraging when nutrients are scarce.

What constitutes a cell in filamentous fungi is ambiguous. The apical compartments of higher filamentous fungi are often multinucleate, and so the process of nuclear replication and segregation into a newly extended septated hyphal compartment is known as the duplication cycle. Thus, Aspergillus nidulans apical compartments contain approximately 50 nuclei per compartment produced during a 2 hour duplication cycle period. Continued septation results in the formation of subapical compartments containing fewer nuclei. Hyphae also commonly branch, usually at some distance behind the leading growing hyphal tip and often just behind a septum in higher fungi. The processes that control branching are not fully elucidated but branch initiation is associated with the appearance of a Spitzenkörper at the site of tip emergence and extension. Mathematical and computational models coupled with experimental data are being used to test our understanding of fungal growth not just at the hyphal tip but across multiple spatio-temporal scales and within communities. Branching allows filamentous fungi to fill space in an efficient and appropriate way, and according to local environmental circumstances. Therefore, fungi colonising nutrient rich substrata branch frequently producing dense mycelia for resource exploitation, whereas hyphae colonising nutrient poor substrata branch less frequently producing effuse mycelia appropriate for resource exploration. 
Rates of branching and tip growth are related to the cytoplasmic volume. Thus, the Hyphal Growth Unit is a measure of the average length of hypha required to support hyphal tip growth. It can be calculated from microscopic preparations growing on agar media as the ratio between the total length of mycelium and the total number of tips. The ratio becomes constant after the initial stages of growth, and is characteristic of each fungal species or strain.

\subsubsection{Population growth}

When yeast or fungal cells are inoculated into a nutrient medium and incubated under optimal physical growth conditions, a typical batch growth curve will result comprising lag, exponential and stationary phases. The lag phase represents a period of zero population growth and reflects the time required for inoculated cells to adapt to their new physical and chemical growth environment (by synthesizing ribosomes and enzymes). The exponential phase is a period of logarithmic cell (or mycelial biomass in the case of filamentous growth) doublings and constant, maximum specific growth rate $\left(\mu_{\max }\right.$, in dimensions of reciprocal time, $\left.\mathrm{h}^{-1}\right)$, the precise value of which depends on the prevailing growth conditions. If growth is optimal and cells double logarithmically, then

$$
\begin{aligned}
& \frac{\mathbf{d x}}{\mathbf{d t}}=\mu_{\max } \mathrm{x} \quad \text { when integrated, this yields } \\
& \ln \mathrm{x}-\ln \mathrm{x}_{\mathrm{O}}=\mu_{\max } \mathrm{t}\left(\text { where } \mathrm{x}_{\mathrm{O}}\right. \text { is the initial cell mass) } \\
& \text { or } \\
& \mathrm{x}=\mathrm{x}_{\mathrm{O}} \mathrm{e}\left(\mu_{\max } \mathrm{t}\right)
\end{aligned}
$$


which is the fundamental equation for exponential batch growth. According to these kinetic expressions a plot of $\ln \mathbf{x}$ versus time is linear with the slope being $\mu_{\max }$ Calculation of the doubling time (td) of a yeast or fungal culture can be achieved from knowledge of $\mu_{\max }$ as follows:

$\mathrm{td}=\frac{\ln 2}{\mu_{\max }}=\frac{\mathbf{0 . 6 9 3}}{\mu_{\max }}$

During the exponential phase of balanced growth, cells are undergoing primary metabolism, explicitly those metabolic pathways that are essential for growth of the cell. Industrial fermentations requiring maximum cell biomass production or the extraction of primary metabolites or their products, therefore aim to extend this phase of growth, often via fed-batch culture (incremental nutrient feeding) or continuous culture techniques (continuous nutrient input with concomitant withdrawal of the biomass suspension).

Following the exponential phase, cells enter a period of zero population growth rate, the stationary phase, in which the accumulated fungal or yeast biomass remains relatively constant and the specific growth rate returns to zero. After prolonged periods in stationary phase, individual cells may die and autolyse (see below). The stationary phase may be defined as cellular survival for prolonged periods (i.e. months) without added nutrients. In addition to nutrient deprivation, other physiological causes may promote entry of fungal cells into stationary phase including: toxic metabolites (e.g. ethanol in the case of yeasts), low $\mathrm{pH}$, high $\mathrm{CO}_{2}$, variable $\mathrm{O}_{2}$ and high temperature. During the stationary phase of unbalanced growth, fungi may undergo secondary metabolism, specifically initiating metabolic pathways that are not essential for growth of cells but are involved in the survival of the organism. The industrial production of fungal secondary metabolic compounds such 
as penicillin and the ergot alkaloids, therefore involves the controlled maintenance of cell populations within a stationary phase of growth. Recently, S. cerevisiae has been grown at near-zero growth rates in specialised cultivations systems called retentostats, in which cells can retain high metabolic capacities and stress resistance. Retaining yeast cells under such maintenance-energy metabolic conditions may have relevance for industrial bioprocesses.

Filamentous fungi tend to grow as floating surface pellicles when cultivated in static liquid culture. In agitated liquid culture, fungi grow either as dispersed filamentous forms, or as pellets of aggregated mycelia subject to species, inoculum size, agitation rate and nutrient availability. Different growth forms will locally experience different micro-environmental conditions which will affect fungal physiology and hence fermentation processes. In fungal biotechnology, cell morphology may directly influence fermentation progress. For example, the rheological properties of the growth medium, oxygen transfer and nutrient uptake may adversely affect bioproduct formation. In the natural environment, fungal populations interact frequently to form often complex dynamic communities which in turn shape ecosystem functioning. Understanding the population growth and functional (physiological) responses of fungi to their local environment is key to the development of predictive models and to our general understanding of the resilience and resistance of fungal communities to environmental perturbations such as climate change.

Yeast or fungal cell immobilization onto inert carriers has many advantages over free cell suspension culture in industrial processes. Cells may be successfully immobilized either by entrapment, aggregation, containment, attachment or deposition. Fungal biofilms represent a natural form of cell immobilization resulting 
from cellular attachment to solid support materials. Yeast biofilms have several practical applications in fermentation biotechnology and are also medically important with regard to colonization of human tissue. Regarding the former case, with dimorphic yeasts such as Kluyveromyces marxianus, filamentous cells with a large surface area may be better suited to immobilization compared with ellipsoidal unicellular yeast forms with a low surface area. In this latter case of pathogenic yeast biofilms, Candida albicans has been shown to adhere to surgical devices such as heart pacemakers and catheters, human epithelial cells and dental acrylic.

\subsubsection{Fungal cell death}

An understanding of the death of fungal cells is important from a fundamental viewpoint because fungi, especially yeasts, represent valuable model systems for the study of cellular ageing and apoptosis (programmed cell death). Recycling and redeployment of cellular material also helps drive the apical growth of filamentous fungi and the mycelium explores and extends through the environment. From a practical perspective, cell death in fungi is pertinent in relation to the following situations: industrial fermentation biotechnology (where high culture viabilities are desired), food preservation (regarding inhibition of spoilage fungal growth), food production (promotion of cellular autolysis for yeast extracts), and clinical mycology (where fungal death is the goal in treatment of human mycoses).

Numerous physical, chemical and biological factors influence fungal cell death, which may be defined as complete and irreversible failure of cells to reproduce. Fungi will die if confronted with excessive heat, extreme cold, high voltage electricity, ionizing radiation, high hydrostatic and osmotic pressures and if exposed to chemical or biological fungicidal agents. When the cells' physiological protection 
responses are insufficient to counteract the cellular damage caused by physical stress, cells will die. In industrial situations, physical treatments can be used to eradicate contaminant fungi. For example, yeasts exposed to elevated temperatures may lead to their thermal death, and this is exploited in the pasteurization of foods and beverages to kill spoilage yeasts.

There are numerous chemical factors influencing survival of fungi. Several external chemical agents act as fungicides including toxic organic compounds, oxygen free radicals and heavy metals. Chemical preservatives are commonly employed as antifungal agents in foodstuffs, including weak acids such as sorbic, benzoic and acetic acids. These agents, which are generally fungistatic rather than fungicidal, act by dissipating plasma membrane proton gradients and depressing cell $\mathrm{pH}$ when they dissociate into ions in the yeast cytoplasm. Similarly, sulphur dioxide which has long been used to eliminate undesirable yeasts (and bacteria) from wine, dissociates within the yeast cell to $\mathrm{SO}_{3}{ }^{2-}$ and $\mathrm{HSO}_{3}{ }^{-}$resulting in a decline in intracellular $\mathrm{pH}$ and this forms the basis of its antizymotic action. Fungicidal acids include medium-chain fatty acids (e.g. decanoic acid) which may cause rapid cell death of yeasts and fungi by disruption of cell membrane integrity. Endogenous chemical factors such as ethanol and other toxic metabolites (e.g. acetaldehyde) produced by fermentative activity, excessive intracellular acidity or alkalinity, inability to protect against oxidative damage or sequester toxic metals, may also prove lethal to fungi. If fungal cells are unable to detoxify or counteract detrimental effects of chemicals, they may die.

Examples of lethal biotic interactions with fungi include direct ingestion (by insects, protozoa), engulfment and lysis (by mycoparasitising fungi), direct predation (by haustoria-mediated processes) and intoxication (by killer toxin producing yeasts). 
Killer yeasts secrete proteinaceous toxins that are lethal to other yeasts but to which the killers themselves are immune. Several yeast species have now been identified as possessing killer character, but the best known is the K1 system in S. cerevisiae. The $\mathrm{K} 1$ toxin from this species acts by binding to cell wall receptors in sensitive yeast cells, followed by plasma membrane channel formation. This latter event causes disruption of membrane permeability, which leads to the death of sensitive cells. Killer cells synthesise a membrane-bound immunity protein that prevents cellular suicide. In recent years, it has been established that some killer yeasts may also possess antimycotic activity against filamentous fungi. This has lead to the potential use of killer yeasts and their toxins as novel antifungal biocontrol agents for combating important fungal pathogens in agriculture. For example, the killer yeast Pichia anomala (Wickerhamomyces anomalus) has been shown to inhibit the growth of grain-storage fungi (Penicillium spp.) and fungal spoilage of fruits (caused by Botrytis cinerea).

With regard to endogenous biotic factors influencing fungal cell survival, several physiological, morphological, genetic and biochemical events may take place leading to 'self-inflicted' death. For example, fungal autolysis may be described as cellular self-digestion and occurs when endogenous (vacuolar) hydrolytic enzymes, notably proteases and carbohydrases, cause dissolution of cytoplasmic proteins and cell wall polysaccharides, respectively. Autolytic enzymatic activity is encouraged during the production of yeast extracts in the food industry by using high temperatures (e.g. $45^{\circ} \mathrm{C}$ ), salt (to encourage plasmolysis) and solvents (to promote lipid dissolution). Exogenous hydrolytic enzymes such as papain can also be used to accelerate cell wall breakdown. 
Genetic factors also influence fungal cell death. For example, cells may commit suicide following DNA damage, presumably to avoid the risk of producing genetically altered progeny. Cellular ageing and apoptotic cell death has been widely studied in yeasts, especially S. cerevisiae, which is a valuable model organism for understanding molecular genetic basis of the ageing process in eukaryotic cells. Beyond a certain finite limit (termed the Hayflick limit) of cell division cycles (generally around 20 in S. cerevisiae), this yeast can generate no further progeny and cells enter a senescent physiological state leading to death. Aged and senescent populations of this yeast can be isolated, together with mutants displaying age-related phenotypes. In S. cerevisiae, UTH (youth) genes have now been identified which appear to influence both stress resistance and longevity.

\subsection{Conclusion}

This Chapter has highlighted the physiological diversity of yeasts and fungi in terms of morphology, growth, metabolism and cell death. Understanding the ways in which fungi interact with their growth environment is crucial in medical mycology to control fungal pathogens and also in industry to exploit yeasts and fungi for production of biotechnological commodities.

\subsection{Further Reading}

Arora D (ed) (2003) Handbook of Fungal Biotechnology (2nd Edn). Marcel Dekker, Inc.

Arora D (ed) (2004) Fungal Biotechnology in Agricultural, Food and Environmental Applications. Marcel Dekker, Inc.

Boswell, G.P. and Davidson, F, A (2012) Modelling hyphal networks. Fungal Biology Reviews 26, 30-38. 
Carlile, M.J., Watkinson, S.C. and Gooday, G.W. (2001) The Fungi. Second Edition. Academic Press, London \& San Diego

Daniel, H-M, Passoth, V and Walker, GM (2011) Eds. Pichia anomala Special Issue of Antonie Van Leeuwenhoek International Journal of Microbiology, Volume 99.

Deak, T (2008) Handbook of Food Spoilage Yeasts (2 ${ }^{\text {nd }}$ Edn). CRC Press/Taylor \& Francis, Boca Raton

Deacon, J (2005). Fungal Biology. (4 ${ }^{\text {th }}$ Edition). Wiley-Blackwell Publishing. Jennings DH \& Lysek G (1999) Fungal Biology; Understanding the Fungal Lifestyle. Bios.

Falconer, R.E.; Otten, W. and White, N.A (2015) Towards modelling the resistance and resilience of 'below-ground' fungal communities: a mechanistic and trait-based approach. Advances in Applied Microbiology 93; pp. 1-44.

Feldmann,H (2012) Yeast. Molecular and Cell Biology. Wiley-VCH Verlag \& Co, Weinheim, Germany

Huberman, L.B; Liu, J; Qin, L. \& Glass, N.L. (2016) Regulation of the lignocellulytic response in filamentous fungi. Fungal Biology Reviews 30: pp 101-111.

Jorgensen, H.; Nielsen, J; Villadsen, J and Mollgaard, H (1995) Metabolic flux distributions in Penicillium chrysogenum during fed-batch cultivations. Biotechnology and Bioengineering 46: 117-131

Moore, D (1998) Fungal Morphogenesis. Cambridge University Press.

Moore, D. and Robson, G.D. (2011) $21^{\text {st }}$ Century Guidebook to Fungi. Cambridge University Press.

Querol, A and Fleet, GH eds (2006) The Yeast Handbook. Vol 1. Biodiversity and Ecophysiology of Yeasts. Vol 2. Yeasts in Food and Beverages. Springer-Verlag: Berlin \& Heidelberg

Sander,J.D. and Joung, J.K. (2014) CRISPR-Cas systems for editing, regulating and targeting genomes. Nature Biotechnology 32: 347-355

Satyanarayana, T \& Kunze, G (2009). Yeast Biotechnology: Diversity and Applications. Springer Science \& Business Media

Schultzhaus, Z.S. and Shaw, B.D. (2015) Endocytosis and exocytosis in hyphal growth. Fungal Biology Reviews 29; pp 43-53.

Vos,T., Hakkaart, X.D.V., de Hulster, E.A.F., van Maris, A.J.A., Pronk, J.T. and Daran-Lapujade, P. (2016) Maintenance-energy requirements and robustness of Saccharomyces cerevisiae at aerobic near-zero specific growth rates. Microbial Cell Factories 15: 111. 
Walker, G.M. (1998) Yeast Physiology and Biotechnology. John Wiley \& Sons, Chichester

Walker, G.M. (2004) Metals in yeast fermentation processes. Advances in Applied Microbiology 54: 197-229.

Walker, G.M. (2009) Yeasts. In: The Desk Encyclopedia of Microbiology. Ed M. Schaechter. Pp1174-1187. Elsevier Inc.: Oxford.

Walker, G.M. (2010) Bioethanol: Science and Technology of Fuel Alcohol. Ventus Publishing ApS, Copenhagen. ISBN 978-87-7681-681-0

[http://bookboon.com/int/student/chemical/bioethanol-science-and-technologyof-fuel-alcohol]

Walker, G.M. (2011) Pichia anomala: cell physiology and biotechnology relative to other yeasts. Antonie Van Leeuwenhoek 99: 25-34

Walker, R.S.K. and Cai, Y. (2016) The fifth annual Sc2.0 and synthetic genomes conference: Synthetic genomes in high gear.

ACS Synth. Biol. 5, 920-922 [DOI: 10.1021/acssynbio.6b00227] 


\section{CHAPTER 1: FIGURE LEGENDS}

\section{LEGENDS TO FIGURES}

Figure 1.1 Scanning electron micrograph of a typical yeast cell. (x10,000). BS, bud scar; BirS, birth scar. (Reproduced with kind permission of Professor Masako Osumi, Japan Women's University, Tokyo".)

Figure 1.2 Transmission electron microscopy of ultrathin sections of a hyphal tip of Fusarium reveals intracellular fine structure. M, mitochondrion; V, vesicles; P, plasma membrane; MT, microtubules; SC, smooth Golgi cisternae; 4 layers of the cell wall $(1,2,3,4)$. The Spitzenkörper appears as a region surrounded by vesicles containing many small particles (from Carlile, Watkinson and Gooday, 2001)

Figure 1.3. Cell envelope structure of the yeast, S. cerevisiae (from Walker, 1998).

Figure 1.4 Electron micrograph of a typical yeast cell. (CW, cell wall; $\mathrm{CM}$, cell membrane; CMI, cell membrane invagination; BS, bud scar; $\mathrm{M}$, mitochondrion, $\mathrm{N}$, nucleus; V, vacuole; ER, endoplasmic reticulum. (Reproduced with kind permission of Professor Masako Osumi, Japan Women's University, Tokyo") 
Table 1.1: Diversity of yeast cell shapes

\begin{tabular}{|c|c|c|}
\hline Cell shape & Description & Examples of yeast genera \\
\hline Ellipsoid & Ovoid shaped cells & Saccharomyces \\
\hline Cylindrical & Elongated cells with hemi-sherical ends & Schizosaccharomyces \\
\hline Apiculate & Lemon-shaped & Hanseniaspora, Saccharomycodes \\
\hline Ogival & $\begin{array}{l}\text { Elongated cell rounded at one end and } \\
\text { pointed at other }\end{array}$ & Dekkera, Brettanomyces \\
\hline Flask-shaped & Cells dividing by bud-fission & Pityrosporum \\
\hline \multirow{4}{*}{$\begin{array}{l}\text { Miscellaneous } \\
\text { shapes }\end{array}$} & Triangular & Trigonopsis \\
\hline & Curved & Cryptococcus (e.g. C. cereanus) \\
\hline & Spherical & Debaryomyces \\
\hline & Stalked & Sterigmatomyces \\
\hline Pseudohyphal & $\begin{array}{l}\text { Chains of budding yeast cells which have } \\
\text { elongated without detachment. }\end{array}$ & Candida (e.g. C. albicans) \\
\hline Hyphal & $\begin{array}{l}\text { Branched or unbranched filamentous cells } \\
\text { which form from germ tubes. Septa may } \\
\text { be laid down by the continuously extending } \\
\text { hyphal tip. Hyphae may give rise to } \\
\text { blastospores }\end{array}$ & Candida albicans \\
\hline Dimorphic & $\begin{array}{l}\text { Yeasts that grow vegetatively in either } \\
\text { yeast or filamentous (hyphal or } \\
\text { pseudohyphal) form. }\end{array}$ & $\begin{array}{l}\text { Candida albicans } \\
\text { Saccharomycopsis fibuligera } \\
\text { Kluyveromyces marxianus } \\
\text { Malassezia furfur } \\
\text { Yarrowia lipolytica } \\
\text { Histoplasma capsulatum }\end{array}$ \\
\hline
\end{tabular}


Table 1.2. The major polymers found in different taxonomical groups of fungi and fungus-like organisms together with the presence of perforate septa in these groups (adapted from Deacon, 2000; Carlile, Watkinson and Gooday, 2001).

\begin{tabular}{|c|c|c|c|}
\hline $\begin{array}{l}\text { Taxonomic } \\
\text { grouping }\end{array}$ & Fibrillar polymers & Matrix polymers & $\begin{array}{l}\text { Perforate septa present or } \\
\text { absent }\end{array}$ \\
\hline $\begin{array}{l}\text { Oomycetes } \\
\text { (no longer considered } \\
\text { to be true fungi) }\end{array}$ & $\begin{array}{l}\beta(1,3), \beta(1,6)- \\
\text { Glucan } \\
\text { Cellulose }\end{array}$ & Glucan & Absent \\
\hline Chytridomycetes & Chitin; glucan & Glucan; & Absent \\
\hline Zygomycetes & Chitin; chitosan & $\begin{array}{l}\text { Polyglucuronic acid; } \\
\text { glucuronomannopro } \\
\text { teins }\end{array}$ & Absent \\
\hline Basidiomycetes & $\begin{array}{l}\text { Chitin; } \beta(1,3)- \\
\beta(1,6) \text { glucans }\end{array}$ & $\begin{array}{l}\alpha(1,3)-\text { Glucan; } \\
\text { xylomannoproteins }\end{array}$ & Present (mostly Dolipore) \\
\hline $\begin{array}{l}\text { Ascomycetes / } \\
\text { Deuteromycetes }\end{array}$ & $\begin{array}{l}\text { Chitin; } \beta(1,3)- \\
\beta(1,6) \text { glucans }\end{array}$ & $\begin{array}{l}\alpha(1,3)-\text { Glucan; } \\
\text { galactomannoprotei } \\
\text { ns }\end{array}$ & $\begin{array}{l}\text { Present (mostly simple with } \\
\text { large central pore) }\end{array}$ \\
\hline
\end{tabular}


Table 1.3 Functional components of an idealised fungal cell

\begin{tabular}{|c|c|}
\hline Organelle or cellular structure & Function \\
\hline Cell envelope & $\begin{array}{l}\text { Comprising: the plasma membrane which acts as a } \\
\text { selectively permeable barrier for transport of } \\
\text { hydrophilic molecules in and out of fungal cells; the } \\
\text { periplasm containing proteins and enzymes unable } \\
\text { to permeate the cell wall; the cell wall which } \\
\text { provides protection, shape and is involved in cell- } \\
\text { cell interactions, signal reception, and specialised } \\
\text { enzyme activities; fimbriae involved in sexual } \\
\text { conjugation; capsules to protect cells from } \\
\text { dehydration and immune cell attack. }\end{array}$ \\
\hline Nucleus & $\begin{array}{l}\text { Relatively small. Containing chromosomes (DNA- } \\
\text { protein complexes) that pass genetic information to } \\
\text { daughter cells at cell division and the nucleolus } \\
\text { which is the site of ribosomal RNA transcription } \\
\text { and processing. }\end{array}$ \\
\hline Mitochondria & $\begin{array}{l}\text { Site of respiratory metabolism under aerobic } \\
\text { conditions and, under anaerobic conditions, for fatty } \\
\text { acid, sterol and amino acid metabolism. }\end{array}$ \\
\hline Endoplasmic reticulum & $\begin{array}{l}\text { Ribosomes on the rough ER are the sites of protein } \\
\text { biosynthesis }\end{array}$ \\
\hline Proteasome & $\begin{array}{l}\text { Multi-subunit protease complexes involved in } \\
\text { regulating protein turnover }\end{array}$ \\
\hline Golgi apparatus and vesicles & $\begin{array}{l}\text { Secretory system for import (endocytosis) and } \\
\text { export (exocytosis) of proteins }\end{array}$ \\
\hline Vacuole & $\begin{array}{l}\text { Intracellular reservoir (amino acids, polyphosphate, } \\
\text { metal ions); proteolysis; protein trafficking; control } \\
\text { of cellular pH. In filamentous fungi, tubular } \\
\text { vacuoles transport materials bi-directionally along } \\
\text { hyphae. }\end{array}$ \\
\hline Peroxisome & $\begin{array}{l}\text { Oxidative utilisation of specific carbon and nitrogen } \\
\text { sources (contain catalase, oxidases). Glyoxysomes } \\
\text { contain enzymes of the glyoxylate cycle. }\end{array}$ \\
\hline
\end{tabular}


Table 1.4. Elemental Requirements of Fungal Cells

Element

Carbon

Hydrogen

Oxygen

Nitrogen

Phosphorus

Potassium

Magnesium

Sulphur

Calcium

Copper

Iron

Manganese

Zinc

Nickel

Molybdenum
Common Sources

Sugars

Protons from acidic environments

Air, $\mathrm{O}_{2}$

$\mathrm{NH}_{4}{ }^{+}$salts, urea, amino acids

Phosphates

$$
\mathrm{K}^{+} \text {salts }
$$

$\mathrm{Mg}^{2}+$ salts

Sulphates, methionine

$\mathrm{Ca}^{2+}$ salts

Cupric salts

Ferric salts. $\mathrm{Fe}^{3+}$ is

chelated by

siderophores and

released as $\mathrm{Fe}^{2+}$

within the cell.

$\mathrm{Mn}^{2+}$ salts

$\mathrm{Zn}^{2+}$ salts

$\mathrm{Ni}^{2+}$ salts

$\mathrm{Na}_{2} \mathrm{MoO}_{4}$
Cellular Functions

Structural element of fungal cells in combination with hydrogen, oxygen and nitrogen. Energy source

Transmembrane proton motive force vital for fungal nutrition. Intracellular acidic $\mathrm{pH}$ (around 5-6) necessary for fungal metabolism Substrate for respiratory and other mixed-function oxidative enzymes. Essential for ergosterol and unsaturated fatty acid synthesis Structurally and functionally as organic amino nitrogen in proteins and enzymes

Energy transduction, nucleic acid and membrane structure Ionic balance, enzyme activity Enzyme activity, cell and organelle structure

Sulphydryl amino acids and vitamins

Possible second messenger in signal transduction

Redox pigments

Haeme-proteins, cytochromes

Enzyme activity

Enzyme activity

Urease activity

Nitrate metabolism, vitamin $\mathrm{B}_{12}$ 
Table 1.5. Diversity of carbon sources for yeast and filamentous fungal growth (adapted from Walker, 1998)

\begin{tabular}{lll} 
Carbon source & Typical Examples & Comments \\
\hline Hexose sugars & D-glucose, D-galactose, & $\begin{array}{l}\text { Glucose metabolized by majority of } \\
\text { yeasts and filamentous fungi }\end{array}$ \\
& D-fructose, D-mannose & $\begin{array}{l}\text { If a yeast does not ferment glucose, it will } \\
\text { not ferment other sugars. If a yeast } \\
\end{array}$ \\
& $\begin{array}{l}\text { ferments glucose, it will also ferment } \\
\text { fructose and mannose, but not necessarily } \\
\text { galactose }\end{array}$
\end{tabular}

Pentose sugars $\quad$ L-arabinose, D-xylose, $\quad$ Some fungi respire pentoses better than D-xyulose, L-rhamnose glucose. S.cerevisiae can utilize xylulose but not xylose

Disaccharides

Maltose, sucrose, lactose, If a yeast ferments maltose, it does not trehalose, melibiose, generally ferment lactose and vice versa. cellobiose, melezitose Melibiose utilization used to distinguish ale and lager brewing yeasts. Large number of yeasts utilize disaccharides. Few filamentous fungi (e.g. Rhizopus nigricans) cannot utilise sucrose.

Trisaccharides

Raffinose, maltotriose

Raffinose only partially used by S.cerevisiae, but completely used by other Saccharomyces spp. (S.carlsbergensis, S.kluyveri)

Oligosaccharides Maltotetraose, Metabolized by amylolytic yeasts, not by maltodextrins brewing strains

Polysaccharides Starch, inulin, cellulose, Polysaccharide-fermenting yeasts are hemicellulose, chitin, rare. Saccharomycopsis spp. and pectic substances.

S.diastaticus can utilize soluble starch; Kluyveromyces spp. possess inulinase. Many filamentous fungi can utilise these depending on extracellular enzyme activity.

Lower aliphatic Methanol, ethanol Respiratory substrates for many fungi. alcohols Several methylotrophic yeasts (e.g. Pichia 
pastoris, Hansenula polymorpha) have industrial potential

Sugar alcohols

Organic acids

Fatty acids

Hydrocarbons

Aromatics

Miscellaneous
Glycerol, glucitol

Acetate, citrate, lactate, malate, pyruvate, succinate

Oleate, palmitate

n-alkanes

Phenol, cresol, quinol, resourcinol, catechol, benzoate

Adenine, uric acid, butylamine, pentylamine, putrescine.

Lignin

'Hard’ keratin
Can be respired by yeasts and a few fungi. Many yeasts can respire organic acids, but few can ferment them

Several species of oleaginous yeasts can assimilate fatty acids as carbon and energy sources

Many yeast and a few filamentous species grown well on $\mathrm{C}_{12}-\mathrm{C}_{18}$ n-alkanes

Few yeasts can utilize these compounds. Several n-alkane utilizing yeasts use phenol as carbon source via the $\beta$ ketoadipate pathway

Some mycelial fungi and yeasts, for example, Arxula adeninivorans and A.terestre can utilize such compounds as sole source of carbon and nitrogen. Can be decayed only by white-rot fungi (basidiomycotina). Little net energy gained directly, but makes available other polysaccharides such as cellulose and hemicellulose.

Keratinophilic fungi. 
Table 1.6. Yeast and fungal metabolism based on responses to oxygen availability

Mode of energy metabolism Examples

Obligate fermentative

\section{Comments}

Naturally occurring

respiratory-deficient yeasts.

Only ferment, even in

presence of oxygen.

Fungi: facultative and

obligate anaerobes

No oxygen requirement for

these fungi. Two categories

exist with respect to the

effects of air:

Facultative anaerobes (e.g.

Aqualinderella and

Blastocladia) and obligate

anaerobes (e.g.

Neocallimastix)

Facultatively fermentative

Crabtree-positive

Saccharomyces cerevisiae

Crabtree-negative Candida utilis

Non-fermentative

Yeasts: Rhodotorula rubra

Fungi: Phycomyces

Gaemannomyces graminis (the take-all fungus)
Such yeasts predominantly ferment high sugarcontaining media in the presence of oxygen.

Such yeasts do not form ethanol under aerobic conditions and cannot grow anaerobically.

Such yeasts do not produce ethanol, either in the presence or absence of oxygen.

Oxygen essential for such (obligately oxidative) fungi

The growth of these is markedly reduced if oxygen partial pressure falls below normal atmospheric. 
Table 1.7. Metals required for fungal growth and metabolic functions (adapted from Walker, 2004)

\begin{tabular}{lcl}
$\begin{array}{l}\text { Metal } \\
\text { ion }\end{array}$ & $\begin{array}{l}\text { Concentration } \\
\text { supplied in growth medium* }\end{array}$ & \multicolumn{1}{c}{ Main cellular functions } \\
Macroelements & & \\
$\mathrm{K}$ & $2-4 \mathrm{mM}$ & $\begin{array}{l}\text { Osmoregulation, enzyme activity } \\
\text { Enzyme activity, cell division }\end{array}$ \\
$\mathrm{Mg}$ & $2-4 \mathrm{mM}$ & \\
& & \\
Microelements & $2-4 \mu \mathrm{M}$ & Enzyme cofactor \\
$\mathrm{Mn}$ & $<\mu \mathrm{M}$ & Second messenger, yeast flocculation \\
$\mathrm{Ca}$ & $1.5 \mu \mathrm{M}$ & Redox pigments \\
$\mathrm{Cu}$ & $1-3 \mu \mathrm{M}$ & Haem-proteins, cytochromes \\
$\mathrm{Fe}$ & $4-8 \mu \mathrm{M}$ & Enzyme activity, protein structure \\
$\mathrm{Zn}$ & $\sim 10 \mu \mathrm{M}$ & Urease activity \\
$\mathrm{Ni}$ & $1.5 \mu \mathrm{M}$ & Nitrate metabolism, vitamin B12 \\
$\mathrm{Mo}$ & $0.1 \mu \mathrm{M}$ & Cobalamin, coenzymes \\
$\mathrm{Co}$ & &
\end{tabular}

* Figures relate to yeast (S. cerevisiae ) growth stimulation, and are dependent on the species/strain and conditions of growth, but they would be generally applicable for fungal growth. 
Table 1.8. Principal Ingredients of Selected Industrial Media for Yeasts and Fungi

\begin{tabular}{|c|c|c|c|c|c|}
\hline $\begin{array}{l}\text { Componen } \\
\text { ts }\end{array}$ & Molasses & Malt Wort & Wine Must & Cheese Whey & $\begin{array}{l}\text { Corn Steep } \\
\text { Liquor }\end{array}$ \\
\hline $\begin{array}{l}\text { Carbon } \\
\text { Sources }\end{array}$ & $\begin{array}{l}\text { Sucrose } \\
\text { Fructose } \\
\text { Glucose } \\
\text { Raffinose }\end{array}$ & $\begin{array}{l}\text { Maltose } \\
\text { Sucrose } \\
\text { Fructose } \\
\text { Glucose } \\
\text { Maltotriose }\end{array}$ & $\begin{array}{l}\text { Glucose } \\
\text { Fructose } \\
\text { Sucrose (trace) }\end{array}$ & Lactose & $\begin{array}{l}\text { Glucose, other } \\
\text { sugars }\end{array}$ \\
\hline $\begin{array}{l}\text { Nitrogen } \\
\text { Sources }\end{array}$ & $\begin{array}{l}\text { Nitrogen } \\
\text { compounds as } \\
\text { unassimilable } \\
\text { proteins. } \\
\text { Nitrogen sources } \\
\text { need to be } \\
\text { supplemented. }\end{array}$ & $\begin{array}{l}\text { Low molecular } \\
\alpha \text {-amino } \\
\text { nitrogen } \\
\text { compounds, } \\
\text { ammonium ions } \\
\text { and a range of } \\
\text { amino acids. }\end{array}$ & $\begin{array}{l}\text { Variable levels } \\
\text { of ammonia } \\
\text { nitrogen, } \\
\text { which may be } \\
\text { limiting. } \\
\text { Range of } \\
\text { amino acids. }\end{array}$ & $\begin{array}{l}\text { Unassimilable } \\
\text { globulin and } \\
\text { albumin proteins. } \\
\text { Low levels of } \\
\text { ammonium and } \\
\text { urea nitrogen. }\end{array}$ & $\begin{array}{l}\text { Amino acids, } \\
\text { protein }\end{array}$ \\
\hline Minerals & $\begin{array}{l}\text { Supply of } \mathrm{P}, \mathrm{K}, \\
\text { and } \mathrm{S} \text { available. } \\
\text { High } \mathrm{K}^{+} \text {levels } \\
\text { may be inhibitory. }\end{array}$ & $\begin{array}{l}\text { Supply of P, K, } \\
\text { Mg and S } \\
\text { available. }\end{array}$ & $\begin{array}{l}\text { Supply of P, K, } \\
\text { Mg and S } \\
\text { available. } \\
\text { High levels of } \\
\text { sulphite often } \\
\text { present. }\end{array}$ & $\begin{array}{l}\text { Supply of P, K, } \\
\text { Mg, S. }\end{array}$ & $\begin{array}{l}\text { Supply of } \\
\mathrm{P}, \mathrm{K}, \mathrm{Mg}, \mathrm{S}\end{array}$ \\
\hline Vitamins & $\begin{array}{l}\text { Small, but } \\
\text { generally adequate } \\
\text { supplies. Biotin is } \\
\text { deficient in beet } \\
\text { molasses. }\end{array}$ & $\begin{array}{l}\text { Supply of } \\
\text { vitamins is } \\
\text { usually } \\
\text { adequate. High } \\
\text { adjuct sugar }\end{array}$ & $\begin{array}{l}\text { Vitamin supply } \\
\text { generally } \\
\text { sufficient. }\end{array}$ & $\begin{array}{l}\text { Wide range of } \\
\text { vitamins present. }\end{array}$ & $\begin{array}{l}\text { Biotin, } \\
\text { pyridoxine, } \\
\text { thiamin }\end{array}$ \\
\hline
\end{tabular}




\begin{tabular}{|c|c|c|c|c|c|}
\hline & & $\begin{array}{l}\text { wort may be } \\
\text { deficient in } \\
\text { biotin. }\end{array}$ & & & \\
\hline $\begin{array}{l}\text { Trace } \\
\text { Elements }\end{array}$ & $\begin{array}{l}\text { Range of trace } \\
\text { metals present, } \\
\text { although } \mathrm{Mn}^{2+} \\
\text { may be limiting. }\end{array}$ & $\begin{array}{l}\text { All supplied, } \\
\text { although } \mathrm{Zn}^{2+} \\
\text { may be limiting. }\end{array}$ & $\begin{array}{l}\text { Sufficient } \\
\text { quantitities } \\
\text { available. }\end{array}$ & $\begin{array}{l}\text { Fe, Zn, Mn, Ca, } \\
\text { Cu present. }\end{array}$ & $\begin{array}{l}\text { Range of trace } \\
\text { Elements present }\end{array}$ \\
\hline $\begin{array}{l}\text { Other } \\
\text { Component } \\
\text { s }\end{array}$ & $\begin{array}{l}\text { Unfermentable } \\
\text { sugars (2-4\%), } \\
\text { organic acids, } \\
\text { waxes, pigments, } \\
\text { silica, pesticide } \\
\text { residues, } \\
\text { carmelized } \\
\text { compounds, } \\
\text { betaine. }\end{array}$ & $\begin{array}{l}\text { Unfermentable } \\
\text { maltodextrins, } \\
\text { pyrazines, hop } \\
\text { compounds. }\end{array}$ & $\begin{array}{l}\text { Unfermentable } \\
\text { pentoses. } \\
\text { Tartaric and } \\
\text { malic acids. } \\
\text { Decanoic and } \\
\text { octanoic acids } \\
\text { may be } \\
\text { inhibitory. } \\
\text { May be } \\
\text { deficient in } \\
\text { sterols and } \\
\text { unsaturated } \\
\text { fatty acids. }\end{array}$ & $\begin{array}{l}\text { Lipids, } \mathrm{NaCl} \text {. } \\
\text { Lactic and citric } \\
\text { acids. }\end{array}$ & $\begin{array}{l}\text { High levels of } \\
\text { lactic acid } \\
\text { present. Fat and } \\
\text { fibre also present }\end{array}$ \\
\hline
\end{tabular}


Table 1.9. Modes of nutrient transport in fungi

\begin{tabular}{|c|c|c|}
\hline $\begin{array}{l}\text { Mode of } \\
\text { nutrient } \\
\text { transport }\end{array}$ & Description & Examples of nutrients transported \\
\hline Free diffusion & $\begin{array}{l}\text { Passive penetration of lipid-soluble } \\
\text { solutes through the plasma membrane } \\
\text { following the law of mass action from } \\
\text { a high extracellular concentration to a } \\
\text { lower intracellular concentration. }\end{array}$ & $\begin{array}{l}\text { Organic acids, short-chain alkanes an } \\
\text { long-chain fatty acids by fungi and } t \\
\text { export of lipophilic metabolites } \\
\text { (e.g. ethanol) and gaseous compound }\end{array}$ \\
\hline $\begin{array}{l}\text { Facilitated } \\
\text { diffusion }\end{array}$ & $\begin{array}{l}\text { Translocates solutes down a } \\
\text { transmembrane concentration gradient } \\
\text { in an enzyme (permease) mediated } \\
\text { manner. As with passive diffusion, } \\
\text { nutrient translocation continues until } \\
\text { the intracellular concentration equals } \\
\text { that of the extracellular medium. }\end{array}$ & $\begin{array}{l}\text { In the yeast, } S . \text { cerevisiae, glucose is } \\
\text { transported in this manner. }\end{array}$ \\
\hline $\begin{array}{l}\text { Diffusion } \\
\text { channels }\end{array}$ & $\begin{array}{l}\text { These operate as voltage-dependent } \\
\text { "gates" to transiently move certain } \\
\text { nutrients ions down concentration } \\
\text { gradients. They are normally closed at } \\
\text { the negative membrane potential of } \\
\text { resting yeast cells but open when the } \\
\text { membrane potential becomes positive. }\end{array}$ & $\begin{array}{l}\text { Ions such as potassium may be } \\
\text { transported in this fashion. }\end{array}$ \\
\hline $\begin{array}{l}\text { Active } \\
\text { transport }\end{array}$ & $\begin{array}{l}\text { The driving force is the membrane } \\
\text { potential and the transmembrane } \\
\text { electrochemical proton gradient } \\
\text { generated by the plasma membrane } \\
\mathrm{H}^{+} \text {-ATPase. The latter extrudes } \\
\text { protons using the free energy of ATP } \\
\text { hydrolysis that enables nutrients to } \\
\text { either enter with influxed protons, as in } \\
\text { "symport" mechanisms, or against } \\
\text { effluxed protons, as in "antiport" } \\
\text { mechanisms. }\end{array}$ & $\begin{array}{l}\text { Many nutrients (sugars, amino } \\
\text { acids, ions) }\end{array}$ \\
\hline
\end{tabular}


Table 1.10. Respiratory chain characteristics of yeasts and fungi (Adapted from Walker, 1998)
Typical Species
Sensitive to Insensitive to

Type

Normal

All aerobic fungi

Cyanide

SHAM $^{2}$

respiration

and low

azide $^{1}$

Classic Yarrowia lipolytica

SHAM Cyanide, high

(and in stationary phase cultures of several yeast species)

New alternative Schizosaccharomyces pombe, Saccharomyces cerevisiae azide

Kluyveromyces lactis

Williopsis saturnus

High azide Cyanide, low

azide, SHAM

${ }^{1}$ The azide-sensitive pathway lacks proton transport capability and accepts electrons from NADH but not from succinate.

${ }^{2}$ SHAM = Salycil hydroxamate. The SHAM-sensitive pathway transports electrons to oxygen also without proton transport, and therefore does not phosphorylate ADP. 
Table 1.11. Modes of vegetative reproduction in yeasts (adapted from Walker 1998)

Mode

Description

Multilateral budding

Bi-polar budding

Unipolar budding

Monopolar budding

Binary fission

Bud fission

Budding from stalks

Ballistoconidiogenesis

Pseudomycelia two.
Buds may arise at any point on the mother cell surface, but never again at the same site.

Branched chaining may occasionally follow multilateral budding when buds fail to separate.

Budding restricted to poles of elongated cells (apiculate or lemonshaped) along their longitudinal axis.

Budding repeated at same site on mother cell surface. Buds originate at only one pole of the mother cell.

A cell septum (cell plate or Schizosaccharomyces cross-wall) is laid down within cells after lengthwise growth and which cleaves cells into

Broad cross-wall at base of bud forms which separates bud from mother.

Buds formed on short denticles or long stalks.

Ballistoconidia are actively discharged from tapering outgrowths on the cell. Cells fail to separate after budding or fission to produce a single filament. Pseudomycelial morphology is quite diverse and the extent of differentiation variable depending on yeast species and growth conditions.
Representative Yeast Genera

Saccharomyces,

Zygosaccharomyces, Torulaspora, Pichia, Pachysolen, Kluyveromyces, Williopsis, Debaryomyces, Yarrowia, Saccharomycopsis,

Lipomyces

Nadsonia, Saccharomycodes, Haneniaspora, Wickerhamia, Kloeckera

Pityrosporum, Trigonopsis

Malassezia

Occasionally found in:

Saccharomycodes, Nadsonia and Pityrosporum

Sterigmatomyces

Bullera, Sporobolomyces

Several yeast species may exhibit 'dimorphism' eg Candida albicans, Saccharomycopsis figuligera. Even S.cerevisiae exhibits pseudohyphal growth depending on conditions. 

Figure 1.1

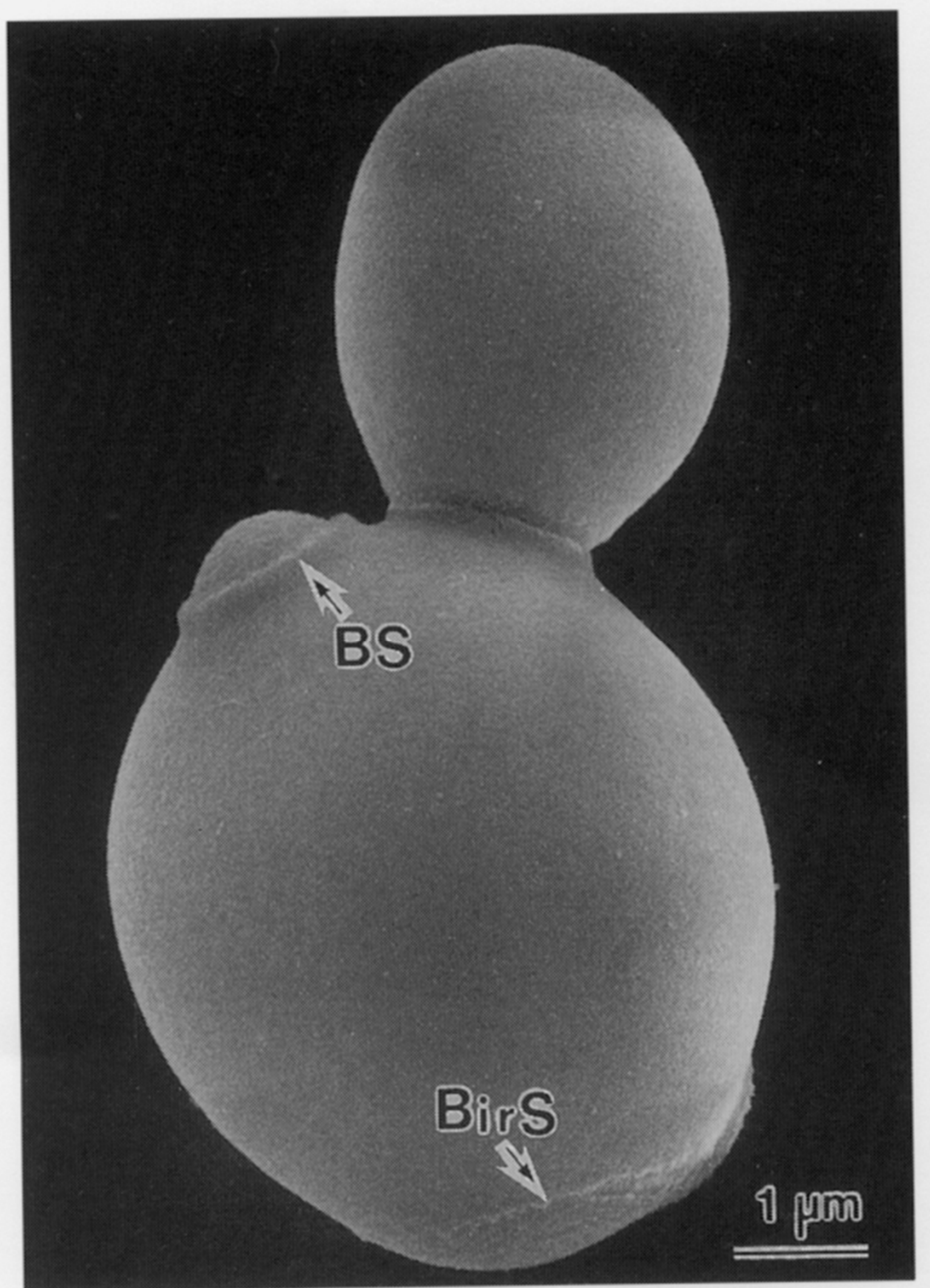


Figure 1.2

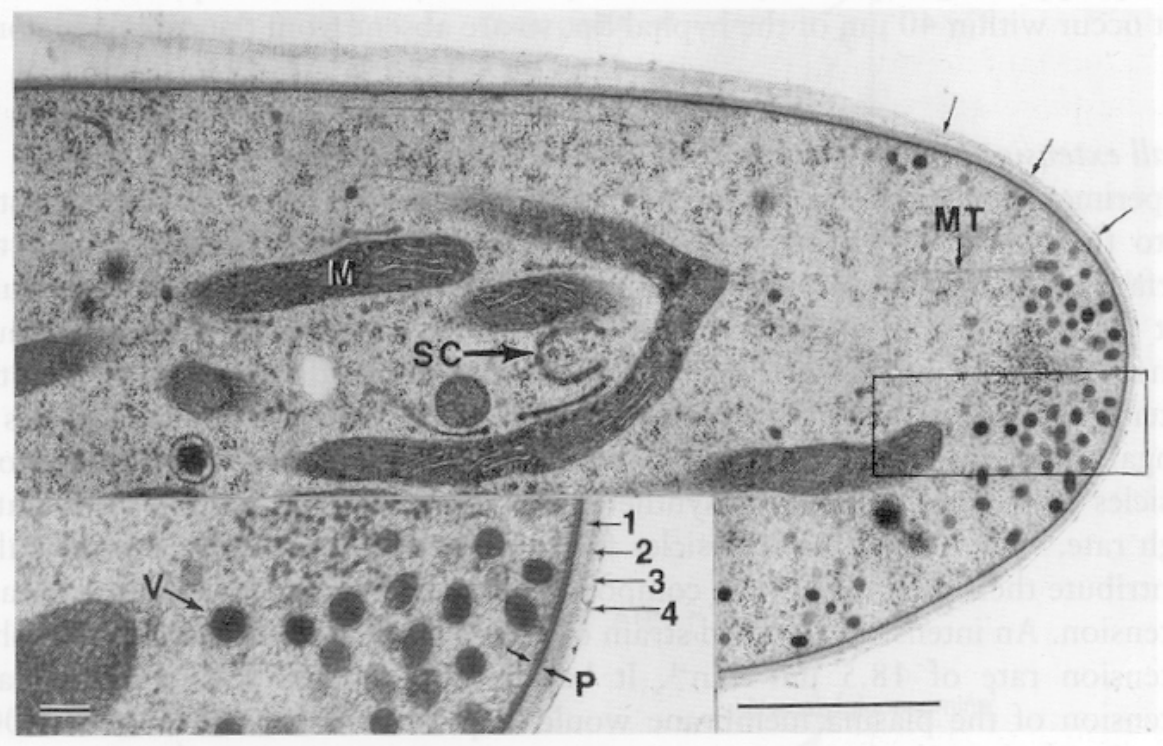


Figure 1.3

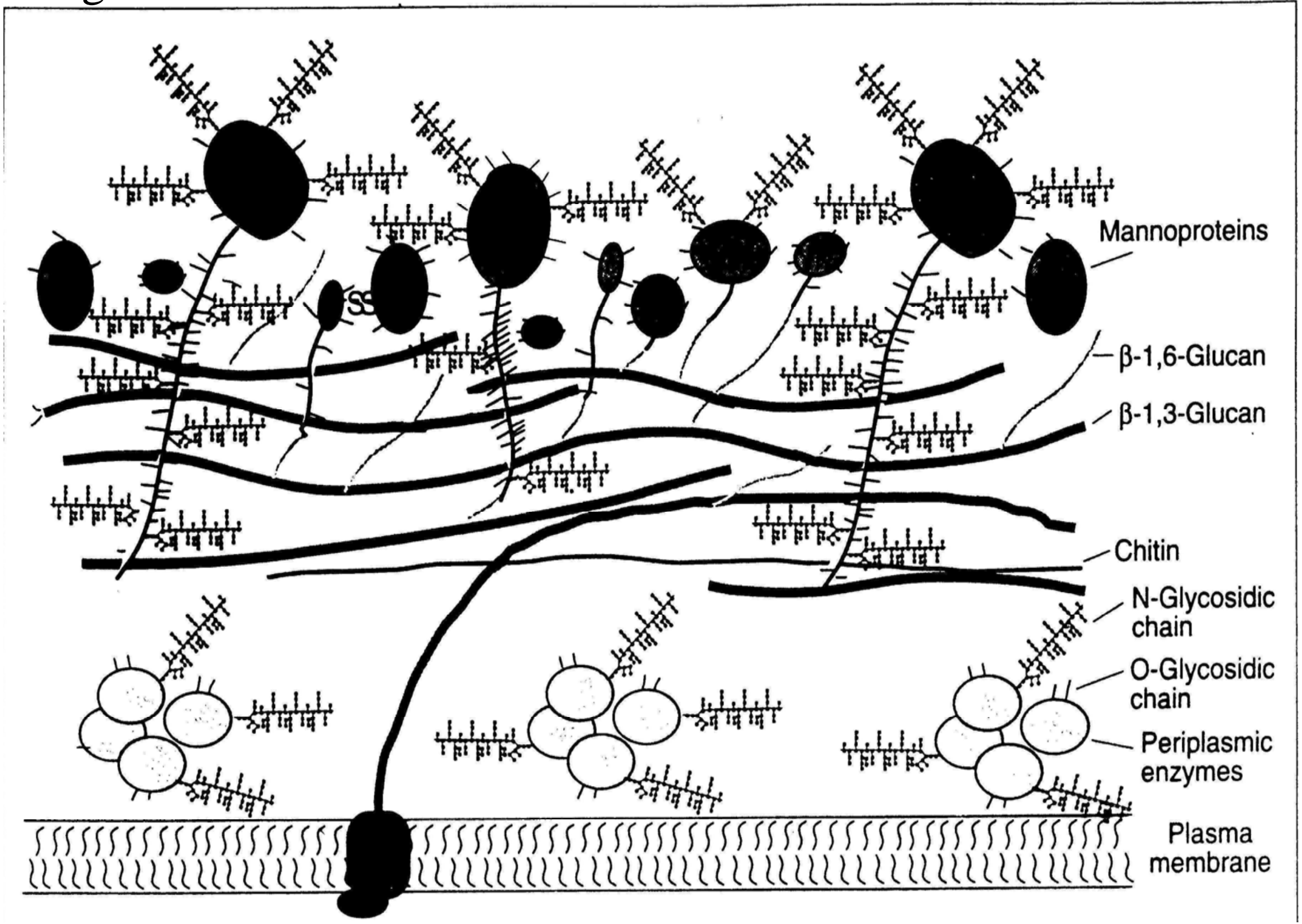




\section{Figure 1.4}

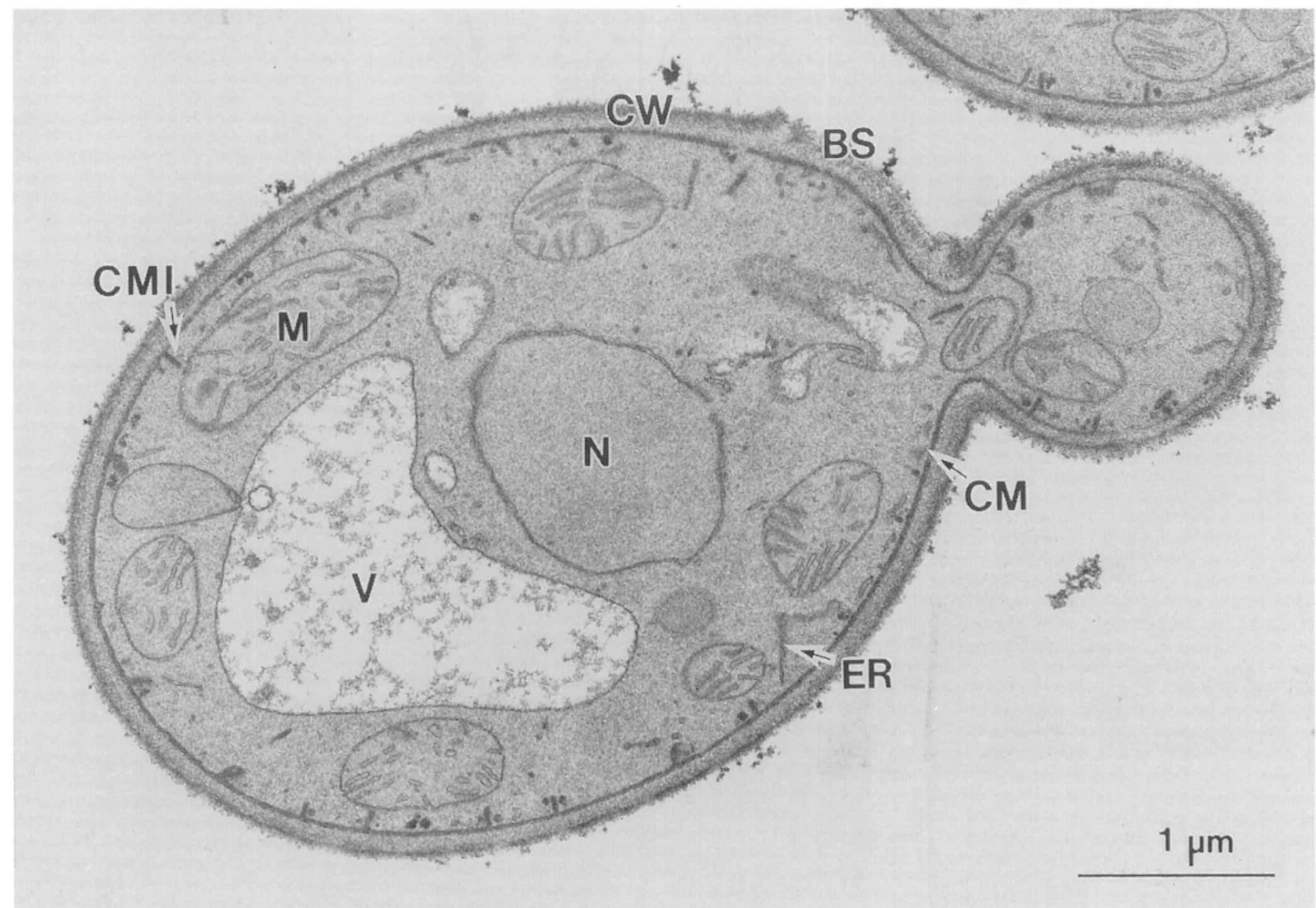

